\title{
Reservoir-System Model for the Willamette River Basin, Oregon
}

River-Quality Assessment of the Willamette River Basin, Oregon

GEOLOGICAL SURVEY CIRCULAR 715-H

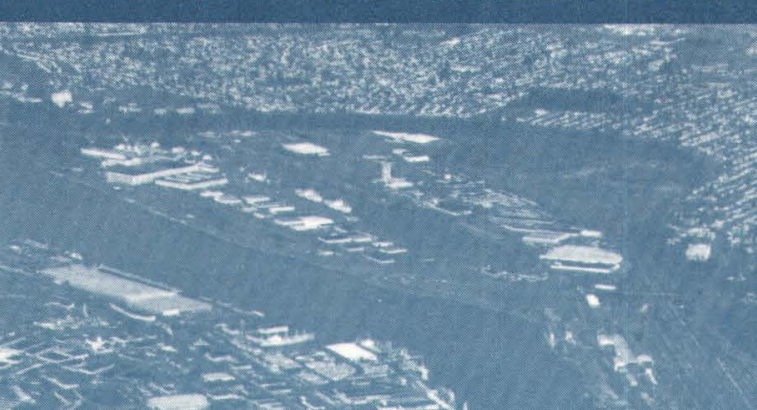

2.

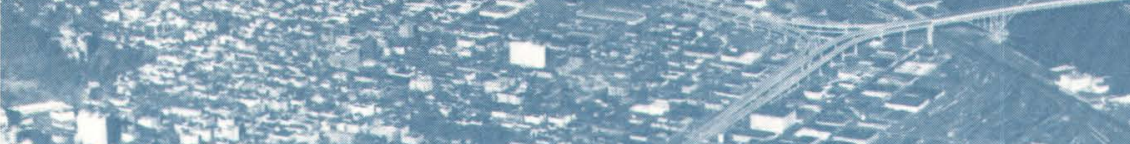
6rom

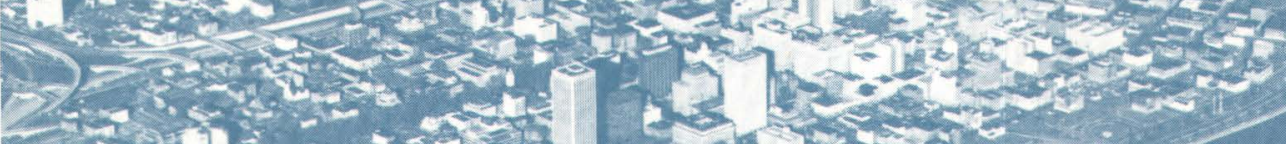







\title{
Reservoir-System Model for the Willamette River Basin, Oregon
}

\author{
By James O. Shearman
}

RIVER-QUALITY ASSESSMENT OF THE WILLAMETTE RIVER BASIN, OREGON

GEOLOGICAL SURVEY CIRCULAR 715-H 


\section{United States Department of the Interior}

\section{THOMAS S. KLEPPE, Secretary}

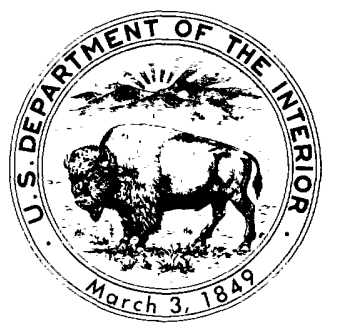

\section{Geological Survey}

V. E. McKelvey, Director

Shearman, James O.

Reservoir-system model for the Willamette River Basin, Oregon. (River-quality assessment of the Willamette River Basin, Oregon)

(U.S. Geological Survey Circular 715-H)

Bibliography: p. 22.

1. Willamette River watershed. 2. Stream measurements-Mathematical models. 3. Stream measurements-Data processing. 4. Reservoirs-Mathematical models. 5. Reservoirs-Data processing. I. Title. II. Series. III. Series: United States Geological Survey Circular 715-H.

QE75.C5 no. 715-H[GB1225.07] 557.3'08s [627'.86'097953] 76-608239 


\section{FOREWORD}

The American public has identified the enhancement and protection of river quality as an important national goal, and recent laws have given this commitment considerable force. As a consequence, a considerable investment has been made in the past few years to improve the quality of the Nation's rivers. Further improvements will require substantial expenditures and the consumption of large amounts of energy. For these reasons, it is important that alternative plans for river-quality management be scientifically assessed in terms of their relative ability to produce environmental benefits. To aid this endeavor, this circular series presents a case history of an intensive river-quality assessment in the Willamette River basin, Oregon.

The series examines approaches to and results of critical aspects of riverquality assessment. The first several circulars describe approaches for providing technically sound, timely information for river-basin planning and management. Specific topics include practical approaches to mathematical modeling, analysis of river hydrology, analysis of earth resources-river quality relations, and development of data-collection programs for assessing specific problems. The later circulars describe the application of approaches to existing or potential river-quality problems in the Willamette River basin. Specific topics include maintenance of high-level dissolved oxygen in the river, effects of reservoir release patterns on downstream river quality, algal growth potential, distribution of toxic metals, and the significance of erosion potential to proposed future land and water uses.

Each circular is the product of a study devoted to developing resource information for general use. The circulars are written to be informative and useful to informed laymen, resource planners, and resource scientists. This design stems from the recognition that the ultimate success of river-quality assessment depends on the clarity and utility of approaches and results as well as their basic scientific validity.

Individual circulars will be published in an alphabetical sequence in the Geological Survey Circular 715 series entitled "River-Quality Assessment of the Willamette River Basin, Oregon."

J. S. Cragwall, Jr.

Chief Hydrologist 
Cover: Willamette River as it winds through Portland, Oregon. Photograph taken by Hugh Ackroyd. 


\section{CONTENTS}

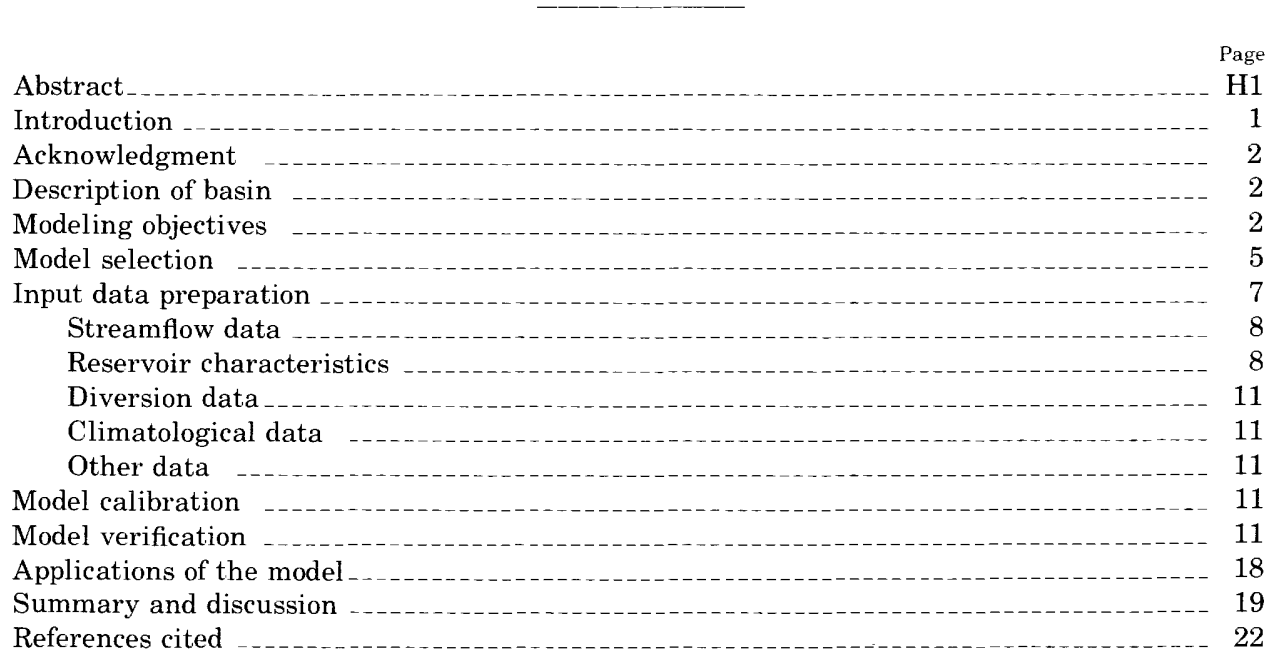

\section{ILLUSTRATIONS}

Figure 1. Map showing study area

2-13. Graphs showing:

2. Frequency-discharge relations at Salem, 1926-73

3. Frequency-discharge relations at Salem computed from short sequences of observed steamflow _..--

4. Relation between annual minimum 7-day and annual minimum 30-day discharges, 1926-71 _...-_

5. Relation between annual minimum 7-day and annual minimum monthly discharges, 1926-71 _..--

6. Typical rule curve of reservoir operation in the Willamette River basin

7. Evaporation relations for the Willamette River basin

8. Distribution of model errors, January 1970 through September 1973

9. Comparison of design, observed, and computed reservoir-system storage

10. Frequency-discharge relations at Salem, 1926-73, computed from simulated streamflow for existing (regulated) conditions and from estimated streamflow for natural (unregulated I conditions _-_- 18

11. Frequency-discharge relations at Salem, 1926-73, computed from simulated streamflows reflecting the existing reservoir system subjected to different estimated flow diversions _............

12. Frequency-discharge relations at Salem, 1926-73, computed from discharges for calendar months 21

13. Frequency-discharge relations at Salem, 1926-73, computed from minimum multimonthly discharge 21

\section{TABLES}

TABLE 1. Selected information for the 13 reservoirs in the Willamette River basin reservoir system

2. Classification of streamflow at Salem relevant to stage of reservoir-system development

3. Relationships used to extend unregulated, monthly streamflow data through 1973

4. Rule curve storage data used in the HEC-3 model

5. Flow diversion data used in the HEC-3 model

6. Summary of model verification results

7. Classification of model errors into absolute error limits 
TABLE 8. Summary of modeling errors with absolute value exceeding 15 percent
9. Summation of total end-of-month storage and monthly storage charges specified by the design rule crrves for

11 reservoirs in the Willamette River basin reservoir system

10. Determination of $Q_{t}$ and ${ }_{t} Q_{7}$ at Salem for the simulated streamflows reflecting the 1970 and 2020 flow diversions

\section{CONVERSION FACTORS}

Factors for converting English units to metric units are listed below. In the text, the metric equivalents are shown only to the number of significant figures consistent with the values for the English units.

Multiply English unit

feet ( $\mathrm{ft}$ )

cubic feet per second $\left(\mathrm{ft}^{3 / \mathrm{s}}\right)$

miles ( $\mathrm{mi}$ )

square miles $\left(\mathrm{mi}^{2}\right)$

acre-feet (acre-ft)

acre-feet (acre-ft)

thousands of acre-feet (acre- $\mathrm{ft} \times 10^{3}$ )

$$
B y
$$

0.3048

0.02832

1.609

2.59

$1.234 \times 10^{-6}$

$1.234 \times 10^{-3}$

1.234
To obtain metric unit

metres (m)

cubic metres per second $\left(\mathrm{m}^{3} / \mathrm{s}\right)$

kilometres $(\mathrm{km})$

square kilometres $\left(\mathrm{km}^{2}\right)$

cubic kilometres $\left(\mathrm{km}^{3}\right)$

cubic hectometres $\left(\mathrm{hm}^{3}\right)$

cubic hectometres $\left(\mathrm{hm}^{3}\right)$ 


\title{
Reservoir-System Model For The Willamette River Basin, Oregon
}

\author{
By James O. Shearman
}

ABSTRACT

Evaluation of basin-development alternatives in terms of potential impacts on river quality for the Willamette River basin, Oregon, requires determining the low-flow characteristics of streamflow resulting from (1) unregulated (natural) conditions and $(2)$ regulated (by existing or alternative reservoir system) conditions. Observed streamflow data that are presently (1973) available are insufficient for reliably estimating these required low-flow characteristics. This report describes (1) a method for estimating monthly streamflow for natural conditions and ( 2 ) the use of a reservoir-system model to simulate monthly streamflow for regulated conditions.

A 4-year period $(1970-73)$ is used to verify the applicability of the U.S. Army Corps of Engineers' HEC-3 reservoir-system model for the Willamette River basin. Modeling errors are computed as the differences between model results and observed streamflow at Salem, Oreg. These errors, although possibly subject to further reduction, are considered to be within reasonable limits.

Simulations of monthly streamflows for a 48-year period (1926-73) are made for four different levels of estimated flow diversions. Each of the simulations uses identical input data for definition of (1) 1926-73 hydrologic data and (2) operation and configuration of the existing reservoir system. Frequency-discharge relations computed from (1) simulated streamflows at Salem reflecting present regulated conditions and (2) estimated streamflows at Salem reflecting natural conditions are used to demonstrate potential applications of the reservoir-system model. Detailed examples illustrate application of these relations for (1) assessing the total impact that the existing reservoir system has had on dissolvedoxygen concentrations at Salem and (2) assessing the impact that the higher flow diversions projected for the future will have on dissolved-oxygen concentrations at Salem. Other potential applications of the reservoir-system model are briefly discussed.

\section{INTRODUCTION}

One objective of the intensive river-quality assessment study of the Willamette River basin, Oregon, was "to develop and document methods for evaluating basin-development alternatives in terms of potential impacts on river quality ***" (Rickert and Hines, 1975). The existing reservoir system in the Willamette River basin represents a very significant component of the overall basin development. Observed streamflow data that are available are not adequate to assess the impact of existing reservoir-system conditions on river quality (see subsequent section, "Modeling Objectives"). Furthermore, any modification of the existing reservoir system would likely have some impact on river quality. Especially significant impact could result from modification of (1) system operation, (2) flow diversions, (3) system configuration, and (4) various combinations of the preceding. River-quality assessment in the Willamette River basin, for either the existing or a modified reservoir system, thus requires a tool for simulating adequate streamflow data. This circular describes a reservoir-system model th at can be used to simulate the required data.

Verification of the model is based on 4 years (1970-73) of observed streamflow at Salem, Oreg. A detailed discussion of the source and magnitude of the modeling errors for the verification period is presented.

Monthly streamflows in the Willamette River basin are simulated for four different levels of flow diversions. All of the simulations are based on input data which define (1) 48 years (1926-73) of hydrologic data and (2) operation ard configuration of the existing reservoir system.

Frequency-discharge relations based on (1) estimated natural flows and (2) simulated flows are utilized to demonstrate potential model applications. All of the examples are based on Willamette River streamflow at Salem, Oreg. However, similar data are available for other points in the basin. Also, simple input data revisions make it possible to simulate streamflows for modified reservoir systems.

The primary purpose of this circular is to dem- 
onstrate the applicability of reservoir-system modeling in river-quality assessment. In view of the fact that time and resources available for the study were limited, simplifying assumptions were made where practical to minimize input data preparation. The resultant limitations of the model used should be examined, and additional refinement of these data considered, before actually using the model for basin planning.

\section{ACKNOWLEDGMENT}

The advice and assistance of the staff of the U.S. Army Corps of Engineers, Portland District Office, the staff of the Texas Water Development Board, and Stuart McKenzie and Dannie Collins, colleagues in the U.S. Geological Survey, are gratefully acknowledged.

\section{DESCRIPTION OF BASIN}

The Willamette River basin, a watershed of nearly $11,500 \mathrm{mi}^{2}\left(29,700 \mathrm{~km}^{2}\right)$ (fig. 1 ), is located in northwestern Oregon between the Cascade and Coast Ranges. Within the basin are the state's three largest cities, Portland, Salem, and Eugene, and approximately 1.4 million people, representing 70 percent of the state's population. The Willamette River basin supports an important timber, agricultural, industrial, and recreational economy and also extensive fish and wildlife habitats.

The basin is roughly rectangular, with a north-south dimension of about $150 \mathrm{mi}(240 \mathrm{~km})$ and an east-west width of $75 \mathrm{mi}(120 \mathrm{~km})$. Elevations above sea level range from less than $10 \mathrm{ft}$ $(3 \mathrm{~m})$ near the mouth of the Willamette River, to $450 \mathrm{ft}(137 \mathrm{~m})$ on the valley floor near Eugene, and to about $10,000 \mathrm{ft}(3,050 \mathrm{~m})$ in the Cascades. The Coast Range generally varies in elevation from 1,000 to $2,000 \mathrm{ft}(305$ to $610 \mathrm{~m})$ but includes peaks of greater than $4,000 \mathrm{ft}(1,220 \mathrm{~m})$.

The main stem of the Willamette River forms at the confluence of its Coast and Middle forks south of Eugene and flows northward for $187 \mathrm{mi}$ $(302 \mathrm{~km})$ through the $3,500 \mathrm{mi}^{2}\left(9,060 \mathrm{~km}^{2}\right)$ Willamette Valley floor. The first $135 \mathrm{mi}(217 \mathrm{~km})$ of the river is characterized by a meandering channel. Through most of the remaining $52 \mathrm{mi}$ $(84 \mathrm{~km})$, the Willamette flows within well-defined banks, unhindered by falls or rapids except for the basaltic intrusion at Oregon City which creates the Willamette Falls. The 26-mi (42-km) reach below the falls is subject to nonsaline tidal effects, transmitted from the Pacific via the Columbia River.

Until recently, the Willamette River has experienced acute water-quality problems related primarily to annually recurring low flow in summer and heavy organic-waste loading by pulp and paper industries. Low-flow augmentation by new reservoirs and new secondary waste-treatment plants has considerably improved the river quality in recent years. However, in light of expected urban and industrial growth, decisionmakers in the basin are now involved with evaluating alternatives for keeping future river-quality conditions at the present high levels.

\section{MODELING OBJECTIVE\&}

The primary objectives of this reservoir-system study for the Willamette River basin are to (1) estimate the magnitude and frequency of low flows at Salem, Oreg., for natural conditionsthat is, the low flows that would have occurred with no significant reservoir develorment in the basin; (2) estimate the magnitude ard frequency of low flows at Salem, Oreg., for the existing reservoir system with reservoir operations and flow diversions that reflect current conditions; and (3) develop practical, quantitative methods for estimating low flows at various control points (fig. 1 ) in the Willamette River basin for alternative reservoir systems.

The first two objectives are of sperific interest because they are directly related to the testing and application of a DO (dissolved oxygen) planning model for the main stem of the Willamette River at Salem, Oreg. This report discusses the application of a reservoir-system model to satisfy the second objective. The first objective is accomplished by using streamflow de.ta that are used as input to the model. The third objective is essential to satisfy specific needs of those agencies or individuals that are responsible for basin planning decisions. Not all of thes needs are presently defined. However, application of the reservoir-system model for estimating reduced low flows at Salem due to increased flow diversions in the basin is demonstrated, and other potential applications are briefly discussed.

Critical DO conditions in the Willamette River basin have occurred only during low-flow periods and only downstream from Salem, Oreg. 


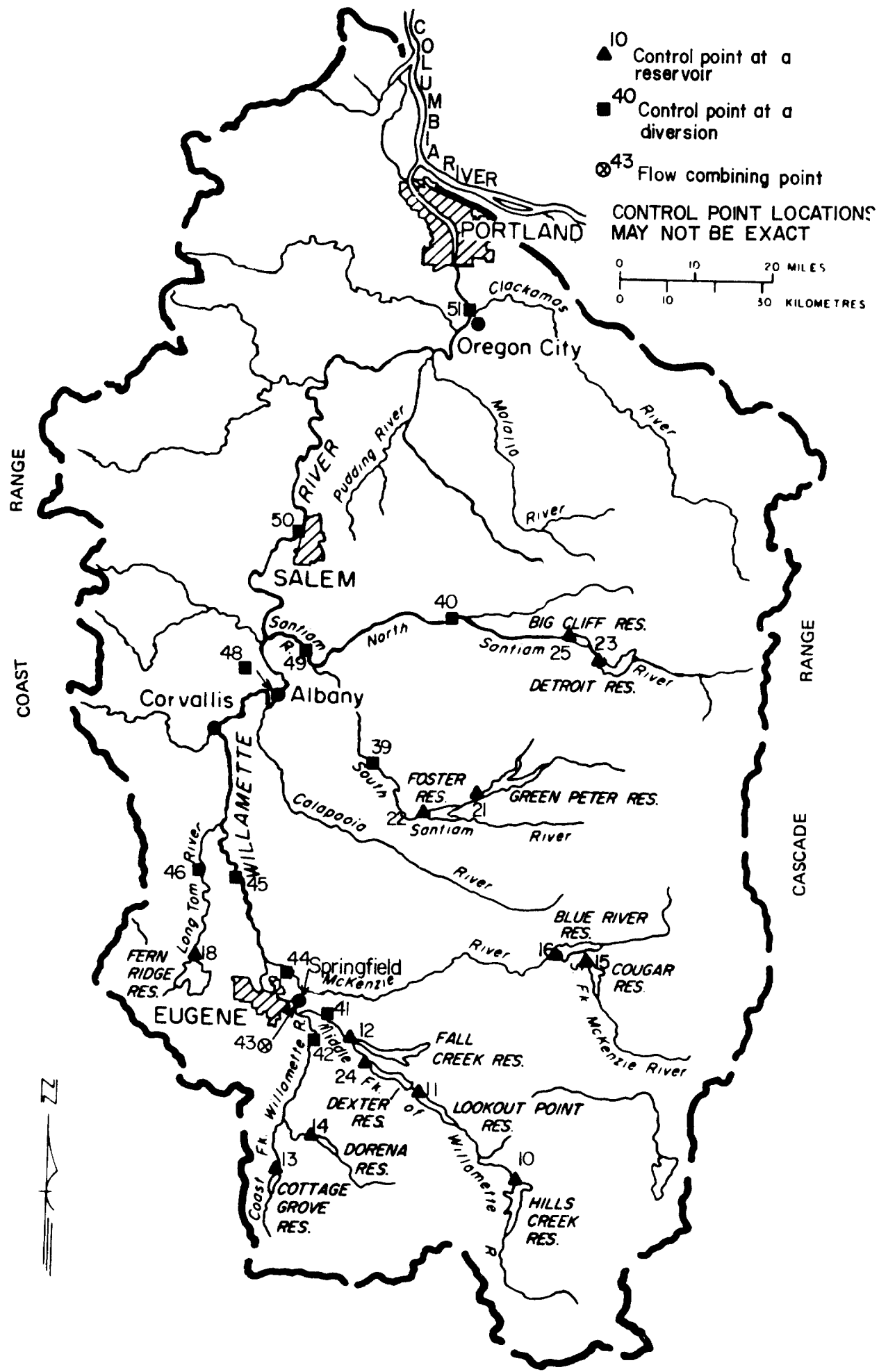

FIGURE 1.-Study area. 
(Gleeson, 1972). Therefore, simulation of the low-flow regime at Salem provides the necessary basis for DO modeling. DO modeling usually requires an estimate of the frequency of recurrence of a minimum flow rate for some duration of time. Minimum 10-, 25-, or 50-year flow rates for consecutive 7-, 14-, or 30-day periods are most commonly used. Such low-flow estimates require a long sequence of homogeneous streamflow data. (Homogeneous, as used herein, implies data resulting from a system that is not radically altered over a period of time.)

The Willamette River basin reservoir system, as defined for this study, is made up of 13 reservoirs. Selected information for the 13 reservoirs is summarized in table 1 . Development of the system began in 1941 with the completion of Fern Ridge reservoir and ended in 1968 with the completion of Blue River reservoir. Total useable storage capacity is about 2 million acre-ft $\left(2.47 \mathrm{~km}^{3}\right.$ ) (Willamette Basin Task Force, 1969 ), about 12 percent of the approximately 17 million acre-ft $\left(21.0 \mathrm{~km}^{3}\right)$ (U.S. Geological Survey, 1973) average annual flow volume of the Willamette River at Salem.

The U.S. Geological Survey has collected continuous streamflow data on the Willamette River at Salem since January 1923. These observed streamflow data reflect the total impact of the reservoir system defined above. Thus, the observed streamflows reflect natural (unregulated) flow conditions until 1941 when minor regulation began. Regulation effects progressively increased until 1968, becoming especially significant in the mid-1950's when about half of the present storage capacity had been developed.
Observed streamflow data at Salem are not adequate for estimating the low-flow cl aracteristics required to satisfy the second objective. Although the data sequence is long enough, the data are not homogeneous. A compariscn of the frequency-discharge relations shown in figure 2 supports this conclusion. These relations are based on 1926-73 data sequences of monthly streamflow at Salem. Classification of these data into four shorter data sequences representing increased stages of reservoir-system development is shown in table 2. Figure 2A, based on observed data, exhibits the expected trend of higher annual minimum-monthly discharges with increased low-flow augmentation from the reservoir system. There is some overlap of the four classes of data as should be expected since the reservoir system does not entirely eliminate variations in reservoir-system inflow. Figure $2 \mathrm{~B}$ is based on the natural (unregulated) monthly flows that were estimated for reservoir-system model input (see "Streamflow Data" subsection of subseauent section "Input Data Preparation"). The more complete mixture of the four classes of data in the latter figure illustrates the nonhomogeneity introduced into the observed data by frogressive reservoir-system development. Nonhcmogeneity is also introduced by other types of basin development (for example, urbanization, changing agricultural practices, and other changing land uses). However, these additional contributing factors are not as easily illustrated and are not as significant as those attributable to reservoirsystem development.

Prediction of the effects of the present Willamette River basin reservoir system could be at-

TABLE 1. Selected information for the 13 reservoirs in the Willamette River basin reservoir system

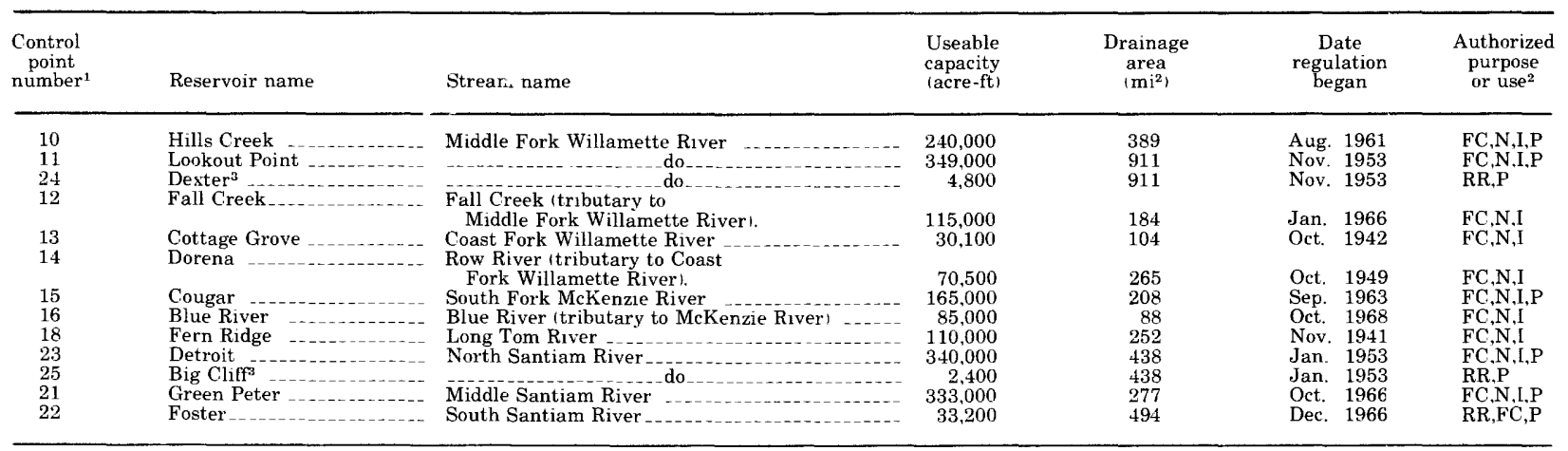




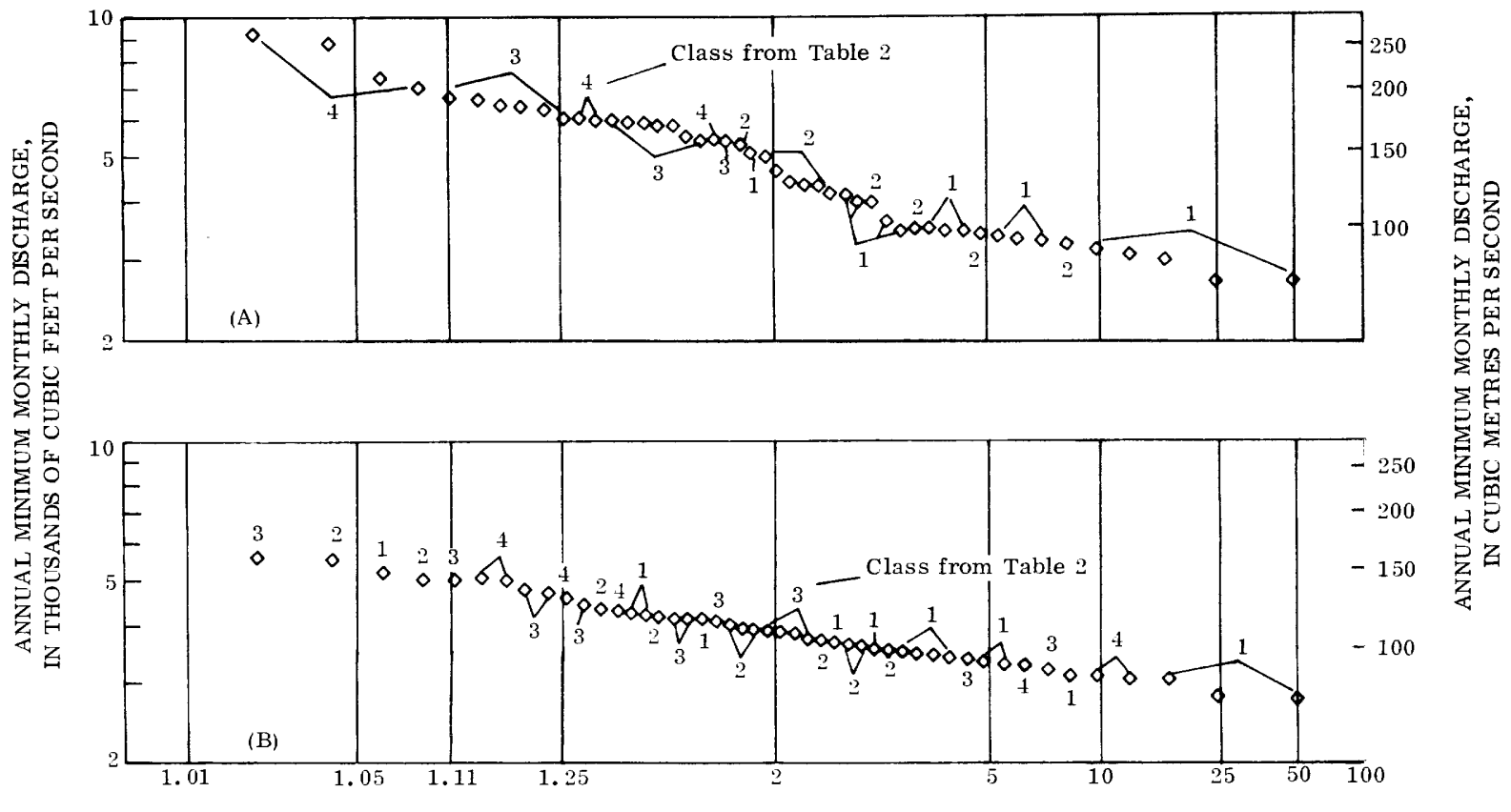

RECURRENCE INTERVAL, IN YEARS

Figure 2.-Frequency-discharge relations at Salem, 1926-73. A, Computed from observed streamflow. B, Computed from estimated natural (unregulated) streamflow.

TABLE 2.-Classification of streamflow at Salem relevant to stage of reservoir-system development

\begin{tabular}{lcc}
\hline Class & Period of record & $\begin{array}{c}\text { Percentage of present total useable } \\
\text { storage capacity developed }\end{array}$ \\
\hline 1 & & 0 \\
2 & $-1926-41$ & $6-11$ \\
3 & $-1942-52$ & $29-76$ \\
4 & $95-100$ \\
\hline
\end{tabular}

tempted by using a portion of the observed streamflow data which could be assumed to be homogeneous. The earliest data that are probably applicable would be for 1967 when 95 percent of the reservoir system had been developed. However, uncertainty exists because it is difficult to determine if the completion of Green Peter and Foster reservoirs (in late 1966) and Blue River reservoir (in late 1968) created any significant nonhomogeneity in the flow data. Figure 3 illustrates the variability of frequency-discharge relations based on four short data sequences that are potentially applicable. Also, Hardison (1969) has shown that increasing the amount of adequate data improves prediction reliability. A data sequence of annual events for 50 years yields predictions that are roughly twice as reliable as a similar data sequence for 10 years.

To satisfy the second modeling objective, an adequate reservoir-system model could' be used to simulate streamflow data sequences. The model would require input data as follows: (1) data describing the present configuration and operation of the reservoir system; (2) a long s?quence of hydrologic data representing system inputs and losses; and (3) data representing the present flow diversions in the basin. Model output would then represent a long sequence of homogeneous streamflow data for existing reservoir-system conditions. Assuming that (1) the motel results are representative of the actual system, (2) the errors associated with the results are within acceptable tolerances, and (3) the limitations of the model are understood and within reason, then the required low-flow estimates can be besed on the simulated data sequence. Furthermore, the same hydrologic data combined with different reservoir-system and (or) flow-diversion data provides the capability to simulate various data sequences that will satisfy the third objective.

\section{MODEL SELECTION}

The major considerations governing model selection were (1) modeling objectives; (2) availability of adequate data; (3) desired accuracy; and (4) available time, manpower, computational 


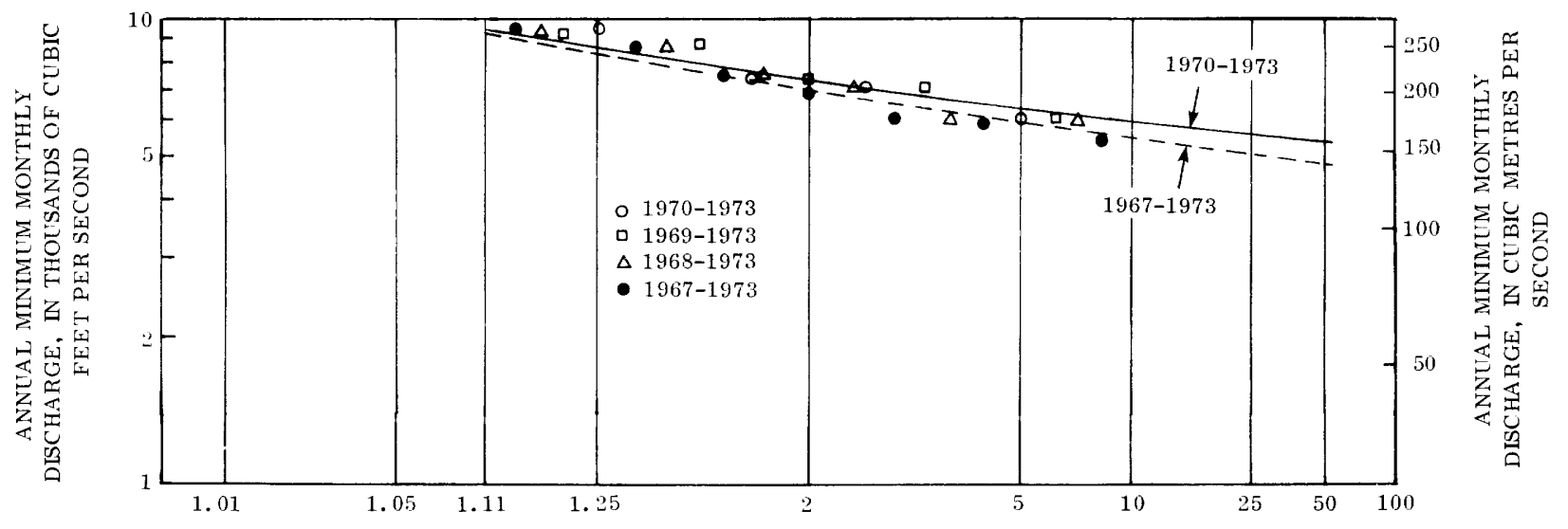

RECURRENCE INTERVAL, IN YEARS

FiguRE 3.-Frequency-discharge relations at Salem computed from short sequences of observed streamflow.

ANNUAL MINIMUM 30-DAY DISCHARGE, IN CUBIC METRES PER SECOND

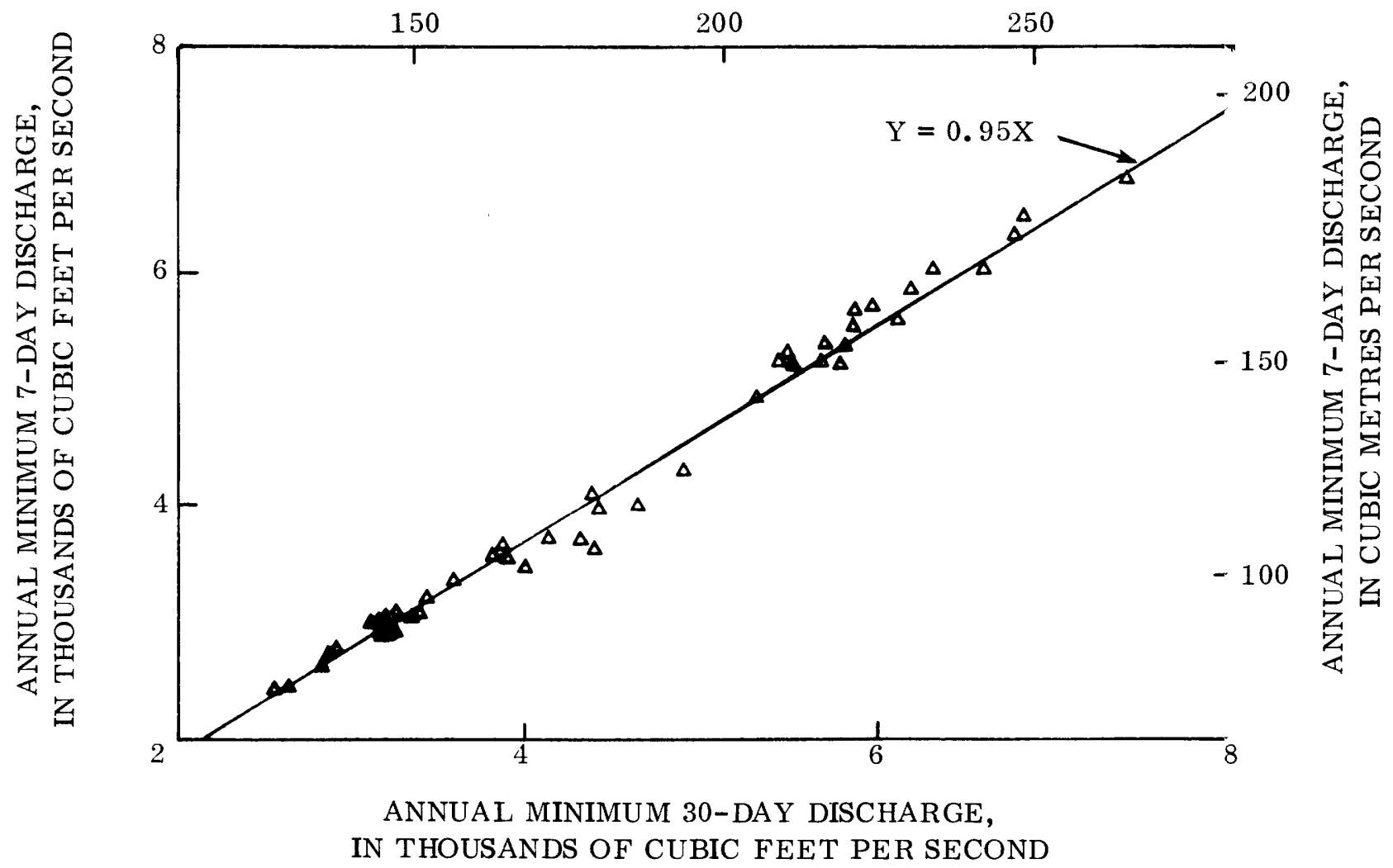

FIGURE 4.--Relation between annual minimum 7-day and annual minimum 30-day discharges, 1926 -71.

facilities, and funds. Manpower and funding limi- $\mid$ possibilities of developing a new model. Theretations, in conjunction with a relatively short project duration (2.5 years), severely limited the fore, two existing reservoir-system models (Jennings and others, 1976) were considered for po- 
tential application to the Willamette River basin reservoir system. These models are the HEC-3 model developed by the U.S. Army Corps of Engineers (1968) and the SIMYLD II model developed by the Texas Water Development Board (1972).

The HEC-3 model exhibited major advantages as follows: (1) 8 of the 13 reservoirs in the Willamette River basin reservoir system are used for power generation, and power-release modeling is possible with HEC-3 but is not possible with SIMYLD II; (2) most of the minimum-flow requirements in the Willamette River basin are variable by season which can be expressed using HEC -3 , but these requirements must be expressed as a yearly average in SIMYLD II; and (3) the more flexible expression of operating rules permitted by HEC-3 made it possible to define better the actual operating rules of the Willamette River basin reservoir system. These limitations of SIMYLD II could have been overcome by additional programing had sufficient time been available.

The Portland District of the Corps of Engineers had used the HEC-3 model for preliminary analyses in the Willamette River basin and had already assembled a considerable amount of directly applicable input data. This advantage, combined with the fact that no revisions of the HEC-3 program were required, resulted in the selection of HEC-3 as the most directly a pplicable reservoir-system model for this study.

\section{INPUT DATA PREPARATIOI ${ }^{\top}$}

The computation time interval selected for the modeling effort was 1 month. Generally, a monthly basis would be inadequate for estimating low flows of short duration. However, the Willamette River at Salem exhibits a very strong relationship between 7-day and 30-day annual minimum low-flow rates. Figure 4 shows this relationship as computed from 1926-71 streamflow data. Figure 5 shows a similar relationship between 7-day and monthly annual minimum low-flow rates. The standard errors of these two relationships are about 3 percent and 18 percent, respectively. The higher error of the latter is due to the fact that the minimum 30-day and minimum monthly flow rates can be sigrificantly different when the 30-day low-flow period overlaps calendar-month boundaries. However, this problem is considerably outweighed by the ad-

ANNUAL MINIMUM MONTHLY DISCHARGE,

IN CUBIC METRES PER SECOND

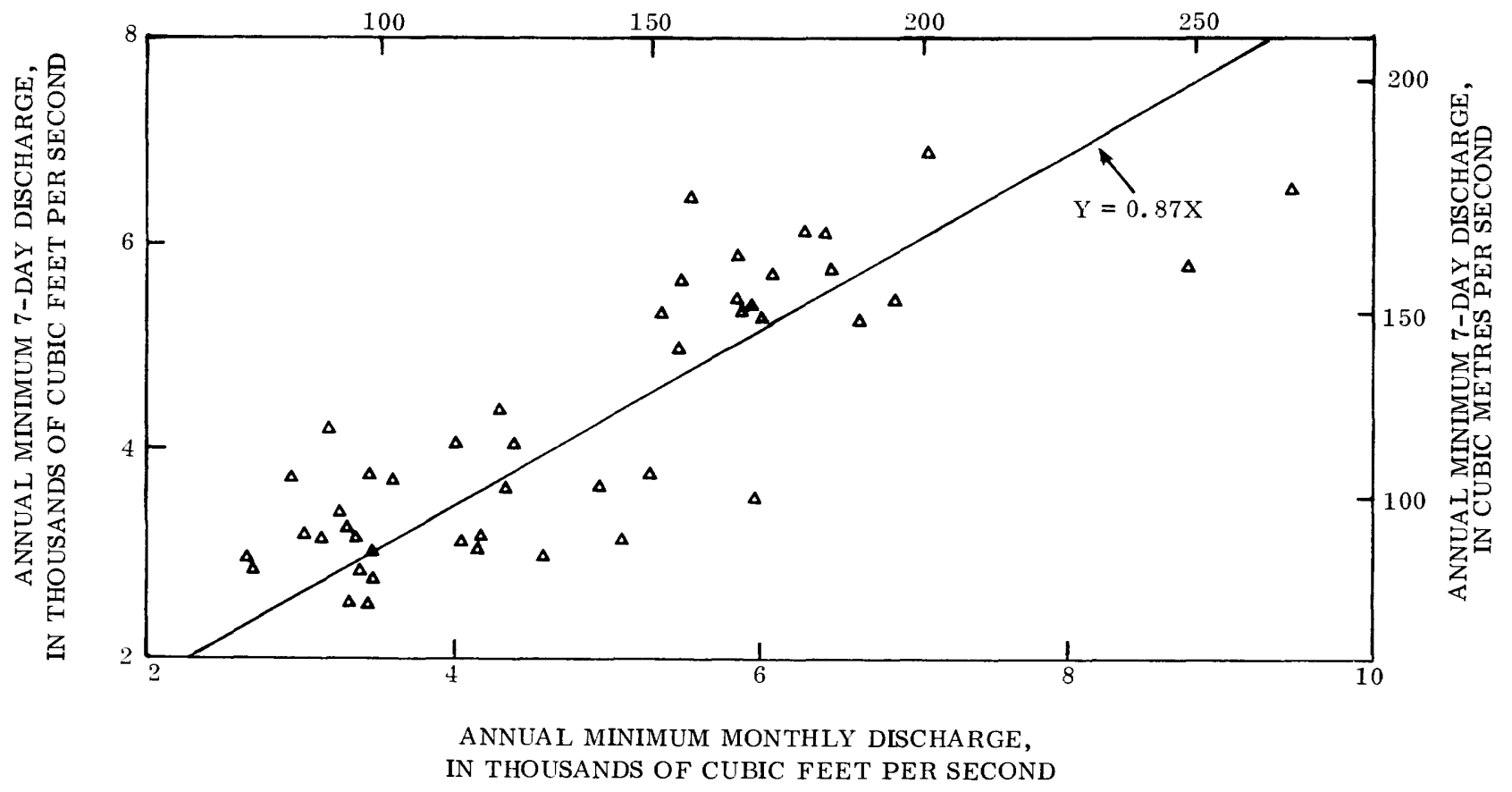

Figure 5.-Relation between annual minimum 7-day and annual minimum monthly discharges, $1926-71$. 
vantages of using monthly data in the model (that is, availability of data and computation reduction). Also, since the total travel time for flows to traverse the length of the basin is only on the order of days, the monthly time frame eliminates the need of any streamflow routing.

\section{STREAMFLOW DATA}

The HEC-3 model requires definition of the total streamflow that would occur at each control point under natural conditions (that is, unaffected by regulation, flow diversions, and so forth). The U.S. Army Corps of Engineers (written commun., 1974) provided adequate input data for unregulated, monthly streamflow at all control points for the period 1926-69. They had developed these data using correlation and waterbudget computations. It was deemed imperative to extend these natural streamflow data through the severe drought year of 1973 (which was also the first year of intensive data collection for DO modeling).

Therefore, at each control point, an attempt was made to develop a relationship for extending the Corps data by correlating the Corps data with observed streamflow at an index station. An index station, in this context, is defined as a streamflow gaging station at which streamflow is unaffected by regulation and (or) diversions. A satisfactory relationship could not always be obtained using a single index station, ir which cases two index stations were used. Selection of the applicable index station(s) for each control point involved a trial-and-error process to simultaneously minimize the standard error and maximize the correlation coefficient of the relationship. At a few control points the relationships developed by using gaging station data were judged inadequate because the standard error was too high and (or) the correlation coefficient was too low. To develop acceptable relationships at these control points it was necessary to use one (or two) upstream control points as the index station(s). Table 3 summarizes the final relationships used for extending the unregulated streamflow for each control point.

\section{RESERVOIR CHARACTERISTICS}

Physical properties of the reservoirs plus power generation data and operating rules were obtained from the Portland District of the U.S. Army Corps of Engineers (written commun., 1974). Figure 6 illustrates a typical operating rule curve that is applicable to each reservoir. The storage data used to define the individual rule curves for the HEC-3 model are tabulated in table 4 .

TABLE 3.-Relationships used to extend unregulated, monthly streamflow through 1973

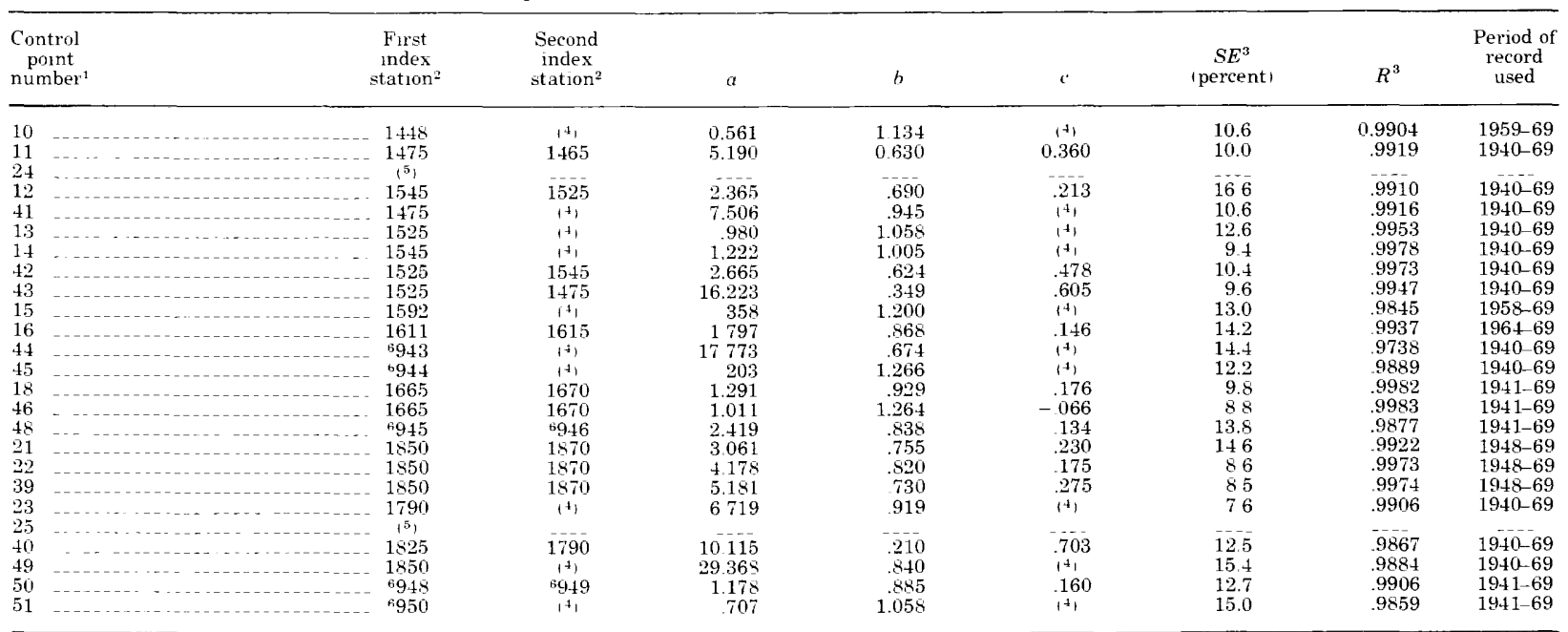

Monthly flow at a control point can be computed by $X=a \mathrm{Y}^{b} Z^{c}$, where $X=$ monthly flow at the control point; $Y=$ monthly flow at the first index station; and $Z=$ monthly flow at the second index station.

${ }^{1}$ See figure 1 for locations and table 1 for reservorr names.

2 Four-digit station numbers are the yvyy portion of the LiSGS gaging-station number 14-yyy 00 .

${ }_{3}^{3} S E$, the standard error of estimate, and $R$. the correlation coefficient, are measures of the goodness of fit of the cornputed data to the observed data 1 Draper and SE, the stan

${ }^{4}$ Best correlation obtained by using only one index station Monthly flows at these control points are computed by $X=a Y b$

${ }^{4}$ Best correlation obtained by using only one index station Monthly flows at these control points are computed by $X=a Y b$.
5These control points are at small reregulating reservoirs just downstream from large reservoirs and require no streamflow data since there is no additional inflow "These control points are at

between the two reservoirs.

${ }^{6}$ Correlation with gaging-station data considered unacceptable. Correlation was made using one lor two upstream control pointısı as index stationısı. $9 x \mathrm{x}$ denotes flows computed at control point $\mathrm{xx}$ using the relationship between control point $\mathrm{xx}$ and its index stationis।. 


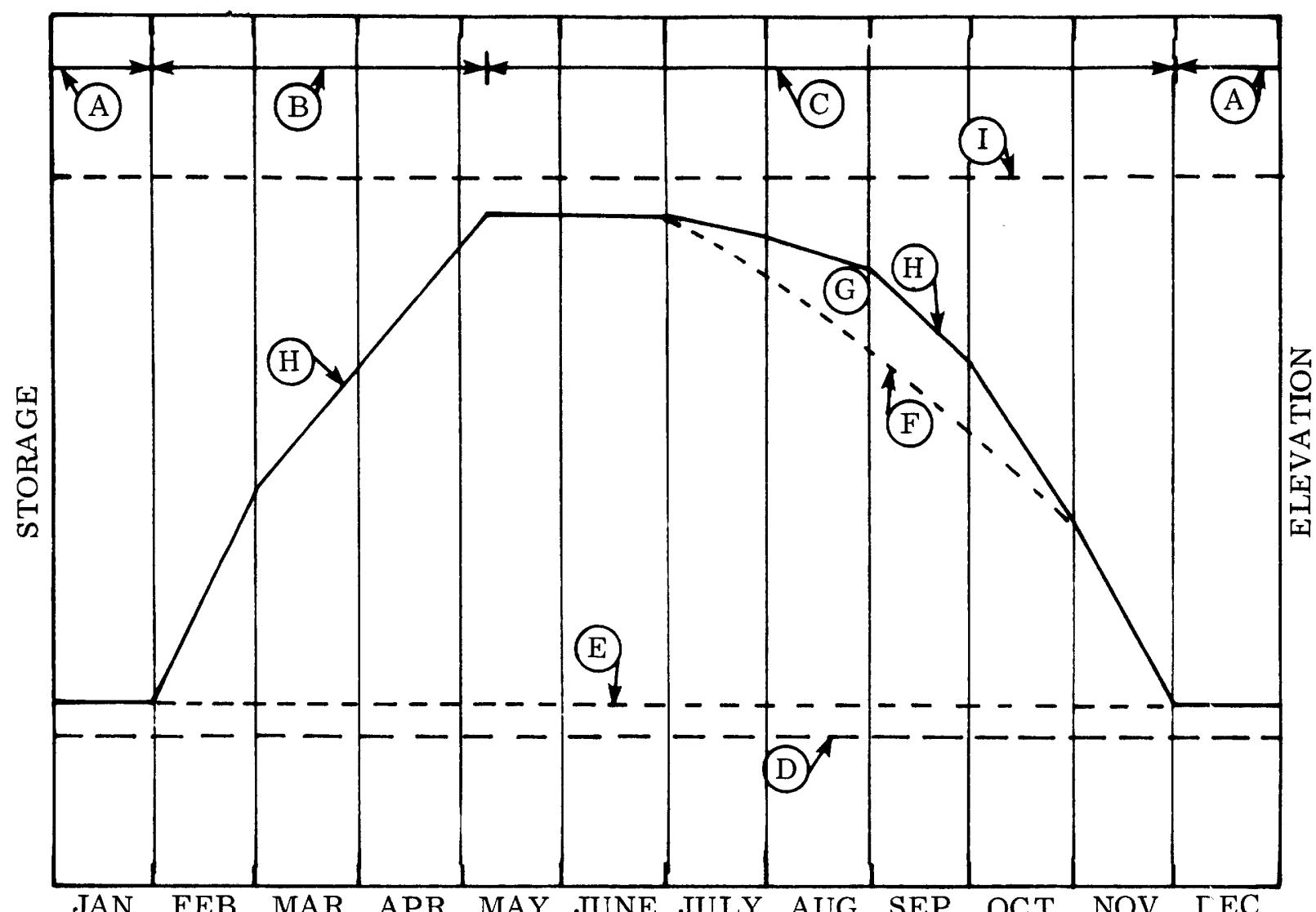

JAN FEB MAR APR MAY JUNE JULY AUG SEP OCT NOV LEC
(A) Major Flood Period--reservoir held to minimum elevation (storage) for flood control.
(B) Conservation Storing Period--reservoir filled for conservation purposes.
(C) Conservation Release Period--stored water released as needed.
(D) Minimum Reservoir Elevation (Storage)--minimum "storage level" specified for $\mathrm{HEC}-3$.
(E) Top of Power Storage--next to lowest "storage level" specified for HEC-3.
F Bottom of flood control pool for "dry conditions" (whereas $\mathrm{H}$ re- presents "ideal", "normal", or "average" conditions.) depletion below "ideal" for various degrees of "below- average" conditions, and among reservoirs in the system.
G. Intermediate "storage levels" may be used to control the rate of
(H) Bottom of Flood Control Pool--next to highest "storage level" specified for $\mathrm{HEC}-3$.
(I) Maximum Reservoir Elevation (Storage)--maximum "storage level" specified for HEC-3.

FIGURE 6.-Typical rule curve of reservoir operation in the Willamette River basin. 
TABLE 4.-Rule curve storage data used in HEC-3

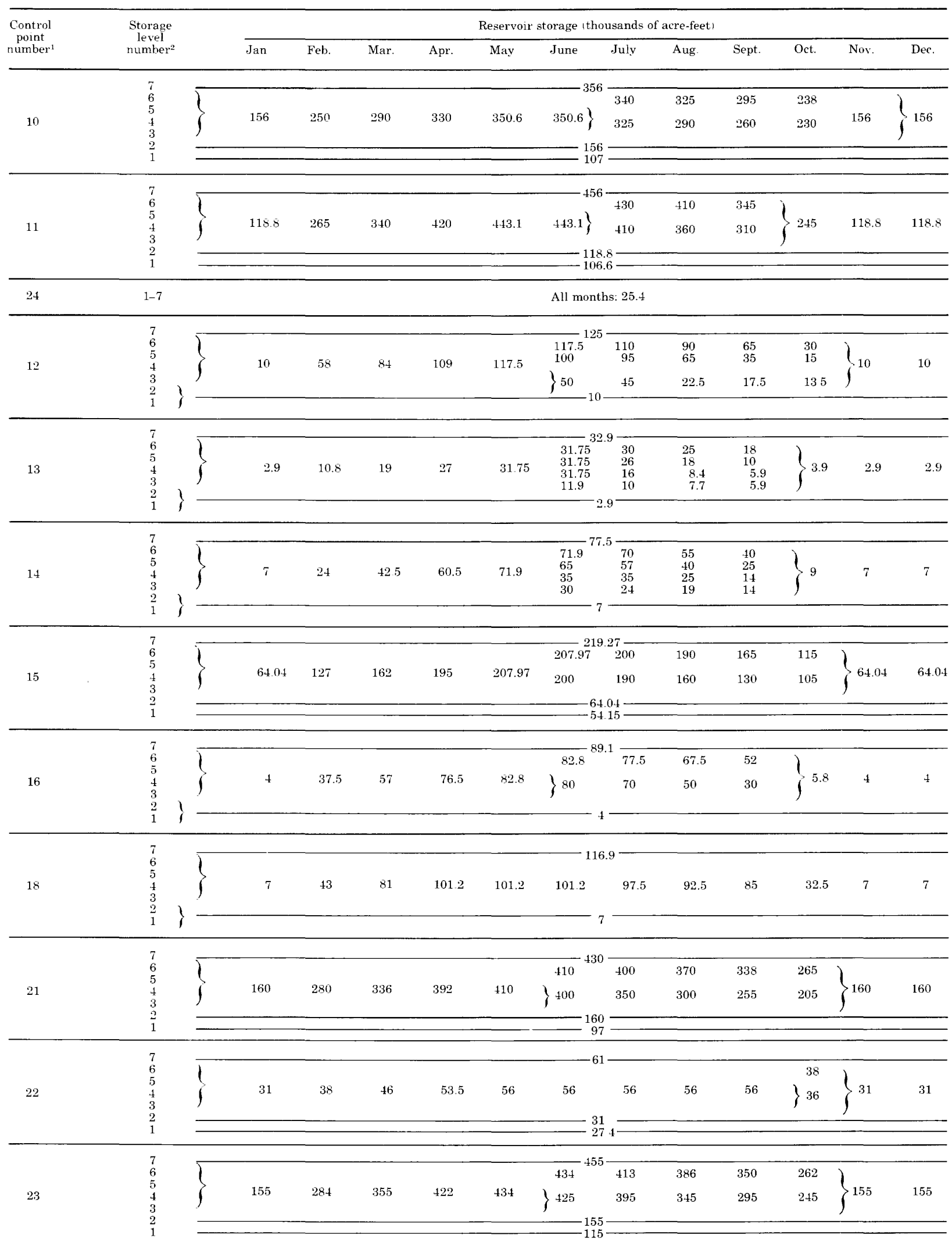


TABLE 4.-Rule curve storage data used in HEC-3-Continued

\begin{tabular}{|c|c|c|c|c|c|c|c|c|c|c|c|c|c|}
\hline \multirow{2}{*}{$\begin{array}{l}\text { Control } \\
\text { point } \\
\text { number }{ }^{1}\end{array}$} & \multirow{2}{*}{$\begin{array}{l}\text { Storage } \\
\text { level } \\
\text { number }\end{array}$} & \multicolumn{12}{|c|}{ Reservoir storage Ithousands of acre-feet । } \\
\hline & & Jan & Feb. & Mar & Apr. & May & June & July & Aug. & Sept. & Oet. & Nor & Dec \\
\hline 25 & $1-7$ & \multicolumn{12}{|c|}{ All months: 4.53} \\
\hline
\end{tabular}

1See figure 1 for locations and table 1 for reservoir names.

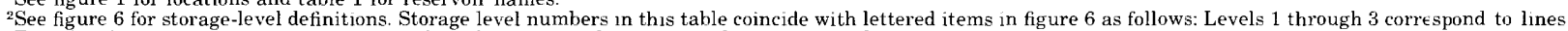
$\mathrm{D}, \mathrm{E}$, and $\mathrm{F}$; levels 4 and 5 are within region $\mathrm{G}$; and levels 6 and 7 correspond to lines $\mathrm{H}$ and $\mathrm{I}$.

\section{DIVERSION DATA}

The Corps also provided the diversion data (written commun., 1974) which they had obtained from the Bureau of Reclamation. These data reflect net depletions attributable to irrigation and municipal and industrial water-supply demands. Table 5 summarizes the estimated net depletions (withdrawals from the system) or return flows (returns of excess withdrawals to the system) for the years $1970,1980,2000$, and 2020 at each diversion point (fig. 1).

\section{CLIMATOLOGICAL DATA}

Evaporation data used in the HEC-3 model are computed from the relationships shown in figure 7. These relationships were obtained from the U.S. Army Corps of Engineers (written commun., 1974). These data, reflecting total evaporation, could be adjusted to reflect net evaporation by adding average basin precipitation to each value. However, this represented a significant data preparation effort and was ignored for the purposes of this report.

\section{OTHER DATA}

The Corps (written commun., 1974) also provided the following miscellaneous data: (1) minimum desired flows at all control points, (2) maximum desired flows at all control points, and (3) all of the data pertaining to shortage declaration (permissible depletion of desired reservoir storage to provide desired flows) in the reservoir system.

\section{MODEL CALIBRATION}

Many types of models (such as DO models and streamflow-routing models) must be calibrated. As discussed by Hines, Rickert, McKenzie, and Bennett (1975), this procedure is required to adjust certain model parameters so that model results (for a particular set of observed input data) adequately represent the observed "real world" results. HEC -3 contains no model parameters of this nature, thereby eliminating the need for calibration.

\section{MODEL VERIFICATION}

An important aspect of any modeling effort is model verification. That is, model results must be compared to observed, "real world" data to judge whether or not the model is a valid predictive tool.

The present reservoir system of 13 reservoirs in the Willamette River basin was not ccmpleted until 1968. To avoid any anomalies that may have existed in the operation of the system with the addition of the last few reservoirs, the period of 1970 through 1973 was selected for the verification procedure. The 1973 reservoir-system configuration and operating rules were defined in the model and 1970 (table 4) diversions were assumed representative of water demands for the verification period. Unregulated monthly streamflow and evaporation data for 1970-73 were used to define the system inputs and losses.

Table 6 (lines 6 and 7) summarizes the streamflow computed by HEC-3 $\left(Q_{c}\right)$ and the observed streamflow $\left(Q_{0}\right)$ for the Willamette Piver at Salem for the period 1970-73. Both monthly and average annual data are shown. Also tabulated (line 8 ) is the total error of each of the computed values (total $Q_{c}$ error in percent of $Q_{o}$ ). Differences between model results and observed average annual streamflow at Salem are considered very acceptable. Comparisons of monthly streamflow values range more widely, from poor to very good.

These total $Q_{c}$ errors are due to differences between the model and the real world for (1) inflows to and losses from the system and (2) definition and operation of the reservoir system. A massvolume balance of an entire reservoir system may be expressed as

$$
I L-Q=\Delta S,
$$

where $I L$ represents an algebraic summation of all inputs to the system and all losses from the 
TABLE 5.-Flow diversion data used in the HEC $\rightarrow 3$ model

\begin{tabular}{|c|c|c|c|c|c|c|c|c|c|c|c|c|c|c|}
\hline \multirow{2}{*}{$\begin{array}{l}\text { Control } \\
\text { point } \\
\text { number }\end{array}$} & \multirow[b]{2}{*}{ Year } & \multicolumn{13}{|c|}{ Net monthly depletion (return flow $1^{2}$ in cubic feet per second } \\
\hline & & & Jan. & Feb. & Mar. & Apr. & May & June & July & Aug & Sept. & Oct. & Nov. & Dec. \\
\hline 41 & $\begin{array}{l}1970 \\
1980 \\
2000 \\
2020\end{array}$ & (1) & $\begin{array}{l}1 \\
1 \\
4 \\
5\end{array}$ & $\begin{array}{l}1 \\
2 \\
5 \\
7\end{array}$ & $\begin{array}{l}1 \\
2 \\
4 \\
6\end{array}$ & $\begin{array}{l}1 \\
2 \\
5 \\
7\end{array}$ & $\begin{array}{r}6 \\
8 \\
14 \\
18\end{array}$ & $\begin{array}{l}19 \\
24 \\
38 \\
52\end{array}$ & $\begin{array}{l}20 \\
26 \\
40 \\
54\end{array}$ & $\begin{array}{l}16 \\
21 \\
34 \\
46\end{array}$ & $\begin{array}{r}5 \\
6 \\
11 \\
17\end{array}$ & $\begin{array}{l}0 \\
(1) \\
0 \\
2\end{array}$ & $\begin{array}{l}1 \\
0 \\
2 \\
4\end{array}$ & $\begin{array}{l}1 \\
1 \\
4 \\
5\end{array}$ \\
\hline 42 & $\begin{array}{l}1970 \\
1980 \\
2000 \\
2020\end{array}$ & - & $\begin{array}{l}3 \\
2 \\
1 \\
5\end{array}$ & $\begin{array}{r}3 \\
4 \\
3 \\
11\end{array}$ & $\begin{array}{r}3 \\
3 \\
3 \\
10\end{array}$ & $\begin{array}{r}3 \\
4 \\
3 \\
10\end{array}$ & $\begin{array}{l}15 \\
24 \\
47 \\
56\end{array}$ & $\begin{array}{r}44 \\
74 \\
148 \\
177\end{array}$ & $\begin{array}{r}47 \\
78 \\
158 \\
187\end{array}$ & $\begin{array}{r}37 \\
64 \\
130 \\
153\end{array}$ & $\begin{array}{r}9 \\
15 \\
34 \\
38\end{array}$ & $\begin{array}{l}(2) \\
(6) \\
(15) \\
(14)\end{array}$ & $\begin{array}{r}(1) \\
(4) \\
(8) \\
110)\end{array}$ & $\begin{array}{l}3 \\
2 \\
1 \\
5\end{array}$ \\
\hline 44 & $\begin{array}{l}1970 \\
1980 \\
2000 \\
2020\end{array}$ & (- & $\begin{array}{r}34 \\
53 \\
83 \\
124\end{array}$ & $\begin{array}{r}33 \\
50 \\
84 \\
124\end{array}$ & $\begin{array}{r}33 \\
51 \\
79 \\
117\end{array}$ & $\begin{array}{r}37 \\
56 \\
86 \\
128\end{array}$ & $\begin{array}{r}67 \\
107 \\
215 \\
305\end{array}$ & $\begin{array}{l}160 \\
245 \\
551 \\
764\end{array}$ & $\begin{array}{l}197 \\
306 \\
657 \\
931\end{array}$ & $\begin{array}{l}161 \\
254 \\
529 \\
740\end{array}$ & $\begin{array}{r}86 \\
138 \\
278 \\
393\end{array}$ & $\begin{array}{r}48 \\
66 \\
104 \\
156\end{array}$ & $\begin{array}{r}38 \\
59 \\
94 \\
137\end{array}$ & $\begin{array}{r}35 \\
56 \\
87 \\
131\end{array}$ \\
\hline 45 & $\begin{array}{l}1970 \\
1980 \\
2000 \\
2020\end{array}$ & 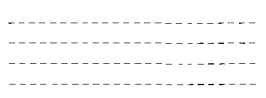 & $\begin{array}{l}|16| \\
129 \\
146 \mid \\
180 \mid\end{array}$ & $\begin{array}{l}|13| \\
|27| \\
|43| \\
|71|\end{array}$ & $\begin{array}{l}(14) \\
(26) \\
(40) \\
(67)\end{array}$ & $\begin{array}{l}151 \\
1281 \\
146 ! \\
1751\end{array}$ & $\begin{array}{c}\{11 \nmid \\
\{16\rceil \\
111 \\
1\end{array}$ & $\begin{array}{r}(5) \\
3 \\
52 \\
151\end{array}$ & $\begin{array}{r}(21) \\
(21) \\
18 \\
108\end{array}$ & $\begin{array}{l}(21) \\
127) \\
12) \\
62\end{array}$ & $\begin{array}{l}(22) \\
(37) \\
(15) \\
(58)\end{array}$ & $\begin{array}{r}1201 \\
1381 \\
1701 \\
11151\end{array}$ & $\begin{array}{l}(14) \\
130) \\
152) \\
192)\end{array}$ & $\begin{array}{l}(16) \\
\mid 31) \\
150 \mid \\
187)\end{array}$ \\
\hline 46 & $\begin{array}{l}1970 \\
1980 \\
2000 \\
2020\end{array}$ & (1) & $\begin{array}{r}9 \\
8 \\
14 \\
19\end{array}$ & $\begin{array}{l}11 \\
10 \\
17 \\
24\end{array}$ & $\begin{array}{r}10 \\
9 \\
16 \\
22\end{array}$ & $\begin{array}{l}11 \\
10 \\
17 \\
23\end{array}$ & $\begin{array}{r}33 \\
54 \\
120 \\
117\end{array}$ & $\begin{array}{r}91 \\
58 \\
365 \\
349\end{array}$ & $\begin{array}{r}98 \\
171 \\
393 \\
377\end{array}$ & $\begin{array}{r}80 \\
139 \\
302 \\
285\end{array}$ & $\begin{array}{r}33 \\
50 \\
122 \\
112\end{array}$ & $\begin{array}{r}11 \\
8 \\
7 \\
9\end{array}$ & $\begin{array}{l}13 \\
10 \\
14 \\
13\end{array}$ & $\begin{array}{r}9 \\
8 \\
14 \\
18\end{array}$ \\
\hline 48 & $\begin{array}{l}1970 \\
1980 \\
2000 \\
2020\end{array}$ & 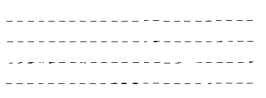 & $\begin{array}{r}17 \\
9 \\
19 \\
7\end{array}$ & $\begin{array}{r}24 \\
17 \\
9 \\
33\end{array}$ & $\begin{array}{r}21 \\
16 \\
9 \\
31\end{array}$ & $\begin{array}{r}22 \\
17 \\
9 \\
33\end{array}$ & $\begin{array}{r}57 \\
84 \\
125 \\
126\end{array}$ & $\begin{array}{l}146 \\
227 \\
400 \\
442\end{array}$ & $\begin{array}{l}148 \\
234 \\
383 \\
410\end{array}$ & $\begin{array}{r}99 \\
140 \\
224 \\
211\end{array}$ & $\begin{array}{l}46 \\
43 \\
22 \\
16\end{array}$ & $\begin{array}{l}16 \\
115\} \\
170\} \\
193 \mid\end{array}$ & $\begin{array}{l}27 \\
10 \\
1351 \\
1341\end{array}$ & $\begin{array}{r}16 \\
1 \\
(5) \\
(6)\end{array}$ \\
\hline 39 & $\begin{array}{l}1970 \\
1980 \\
2000 \\
2020\end{array}$ & - & $\begin{array}{r}17 \\
16 \\
119 \\
18\end{array}$ & $\begin{array}{c}19 \\
17 \\
111 \\
2\end{array}$ & $\begin{array}{l}18 \\
17 \\
19 \\
2\end{array}$ & $\begin{array}{c}19 \\
17 \\
10 \\
2\end{array}$ & $\begin{array}{r}41 \\
49 \\
231 \\
232\end{array}$ & $\begin{array}{l}105 \\
126 \\
754 \\
768\end{array}$ & $\begin{array}{l}112 \\
139 \\
811 \\
829\end{array}$ & $\begin{array}{r}83 \\
102 \\
551 \\
543\end{array}$ & $\begin{array}{r}47 \\
53 \\
179 \\
190\end{array}$ & $\begin{array}{l}21 \\
17 \\
153 \mid \\
154 \mid\end{array}$ & $\begin{array}{l}24 \\
23 \\
1341 \\
121\}\end{array}$ & $\begin{array}{l}14 \\
15 \\
118\} \\
117\end{array}$ \\
\hline 40 & $\begin{array}{l}1970 \\
1980 \\
2000 \\
2020\end{array}$ & (1) & $\begin{array}{r}63 \\
87 \\
109 \\
140\end{array}$ & $\begin{array}{r}66 \\
92 \\
113 \\
142\end{array}$ & $\begin{array}{r}62 \\
85 \\
104 \\
131\end{array}$ & $\begin{array}{r}65 \\
90 \\
109 \\
138\end{array}$ & $\begin{array}{l}157 \\
236 \\
342 \\
405\end{array}$ & $\begin{array}{r}374 \\
548 \\
890 \\
1,044\end{array}$ & $\begin{array}{r}422 \\
631 \\
994 \\
1.185\end{array}$ & $\begin{array}{l}320 \\
475 \\
758 \\
898\end{array}$ & $\begin{array}{l}174 \\
250 \\
389 \\
478\end{array}$ & $\begin{array}{r}60 \\
78 \\
105 \\
135\end{array}$ & $\begin{array}{r}66 \\
91 \\
110 \\
1+1\end{array}$ & $\begin{array}{r}63 \\
86 \\
111 \\
137\end{array}$ \\
\hline 49 & $\begin{array}{l}1970 \\
1980 \\
2000 \\
2020\end{array}$ & 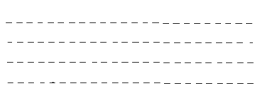 & $\begin{array}{l}1 \\
4 \\
0 \\
0\end{array}$ & $\begin{array}{l}3 \\
6 \\
3 \\
4\end{array}$ & $\begin{array}{l}2 \\
6 \\
2 \\
4\end{array}$ & $\begin{array}{l}3 \\
6 \\
2 \\
4\end{array}$ & $\begin{array}{r}5 \\
14 \\
17 \\
35\end{array}$ & $\begin{array}{r}11 \\
33 \\
51 \\
123\end{array}$ & $\begin{array}{r}9 \\
31 \\
43 \\
120\end{array}$ & $\begin{array}{r}3 \\
16 \\
22 \\
68\end{array}$ & $\begin{array}{c}0 \\
4 \\
(3) \\
14\end{array}$ & $\begin{array}{c}0 \\
|3| \\
|11| \\
|19|\end{array}$ & $\begin{array}{c}2 \\
3 \\
141 \\
17 \mid\end{array}$ & $\begin{array}{c}1 \\
\Sigma \\
0 \\
44\}\end{array}$ \\
\hline 50 & $\begin{array}{l}1970 \\
1980 \\
2000 \\
2020\end{array}$ & - & $\begin{array}{l}(17) \\
(34) \\
(34) \\
(18)\end{array}$ & $\begin{array}{r}\{14\} \\
\{331 \\
+28 \mid \\
191\end{array}$ & $\begin{array}{r}115\} \\
\{29\} \\
125\} \\
181\end{array}$ & $\begin{array}{l}116 \mid \\
131 \mid \\
127 \mid \\
19 \mid\end{array}$ & $\begin{array}{r}39 \\
90 \\
150 \\
194\end{array}$ & $\begin{array}{l}161 \\
338 \\
568 \\
722\end{array}$ & $\begin{array}{l}175 \\
384 \\
591 \\
756\end{array}$ & $\begin{array}{l}107 \\
230 \\
377 \\
469\end{array}$ & $\begin{array}{r}22 \\
47 \\
84 \\
129\end{array}$ & $\begin{array}{l}1301 \\
(67) \\
1851 \\
195)\end{array}$ & $\begin{array}{l}(21) \\
(51) \\
(72) \\
(65)\end{array}$ & $\begin{array}{l}122) \\
(49) \\
1381 \\
1351\end{array}$ \\
\hline 51 & $\begin{array}{l}1970 \\
1980 \\
2000 \\
2020\end{array}$ & 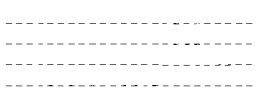 & $\begin{array}{l}24 \\
111 \\
118 \\
29\end{array}$ & $\begin{array}{r}45 \\
21 \\
53 \\
113\end{array}$ & $\begin{array}{r}41 \\
28 \\
48 \\
110\end{array}$ & $\begin{array}{r}44 \\
27 \\
48 \\
105\end{array}$ & $\begin{array}{l}300 \\
463 \\
877 \\
864\end{array}$ & $\begin{array}{r}883 \\
1,370 \\
2.797 \\
2,892\end{array}$ & $\begin{array}{r}966 \\
1,538 \\
2,971 \\
2,968\end{array}$ & $\begin{array}{r}631 \\
964 \\
2.134 \\
1,955\end{array}$ & $\begin{array}{l}239 \\
304 \\
668 \\
610\end{array}$ & $\begin{array}{r}141\rangle \\
(160) \\
1239 \prime \\
|295|\end{array}$ & $\begin{array}{l}28 \\
1521 \\
1831 \\
1881\end{array}$ & $\begin{array}{l}14 \\
(17) \\
(16) \\
10\end{array}$ \\
\hline
\end{tabular}

ISee figure 1 for locations.

2Values in parentheses indicate return flows

system, $Q$ is the system output, and $\Delta S$ is the net summation of the storage change in all reservoirs in the system. The $I L$ term is not directly observed (nor directly computed by the model) but can be estimated from observed (or computed) values of $Q$ and $\Delta S$. Therefore, rewriting equation 1 and subscripting with $o$ for terms related to observed data and $c$ for terms related to computed values (model results) yields

$$
I L_{o}=Q_{o}+\Delta S_{o}
$$

and

$$
I L_{c}=Q_{c}+\Delta S_{c}
$$

Table 6 (lines 1-3) summarizes the values of $I L_{o}, I L_{c}$, and the $I L_{c}$ error. The latter term is computed as

$$
I L_{c} \text { error }=\frac{I L_{c}-I L_{o}}{I L_{o}} \times 100 .
$$

Also tabulated are the $\Delta S_{o}$ and $\Delta S_{c}$ values (lines 4 and 5 ). The small reregulating reservoirs (Big Cliff and Dexter) are not included in $\Delta S$ because (1) observed data are not available and (2) there was a constant zero storage change for these reservoirs in the HEC-3 model. Over 90 percent of the $I L_{c}$ values, which are based on the model re- 


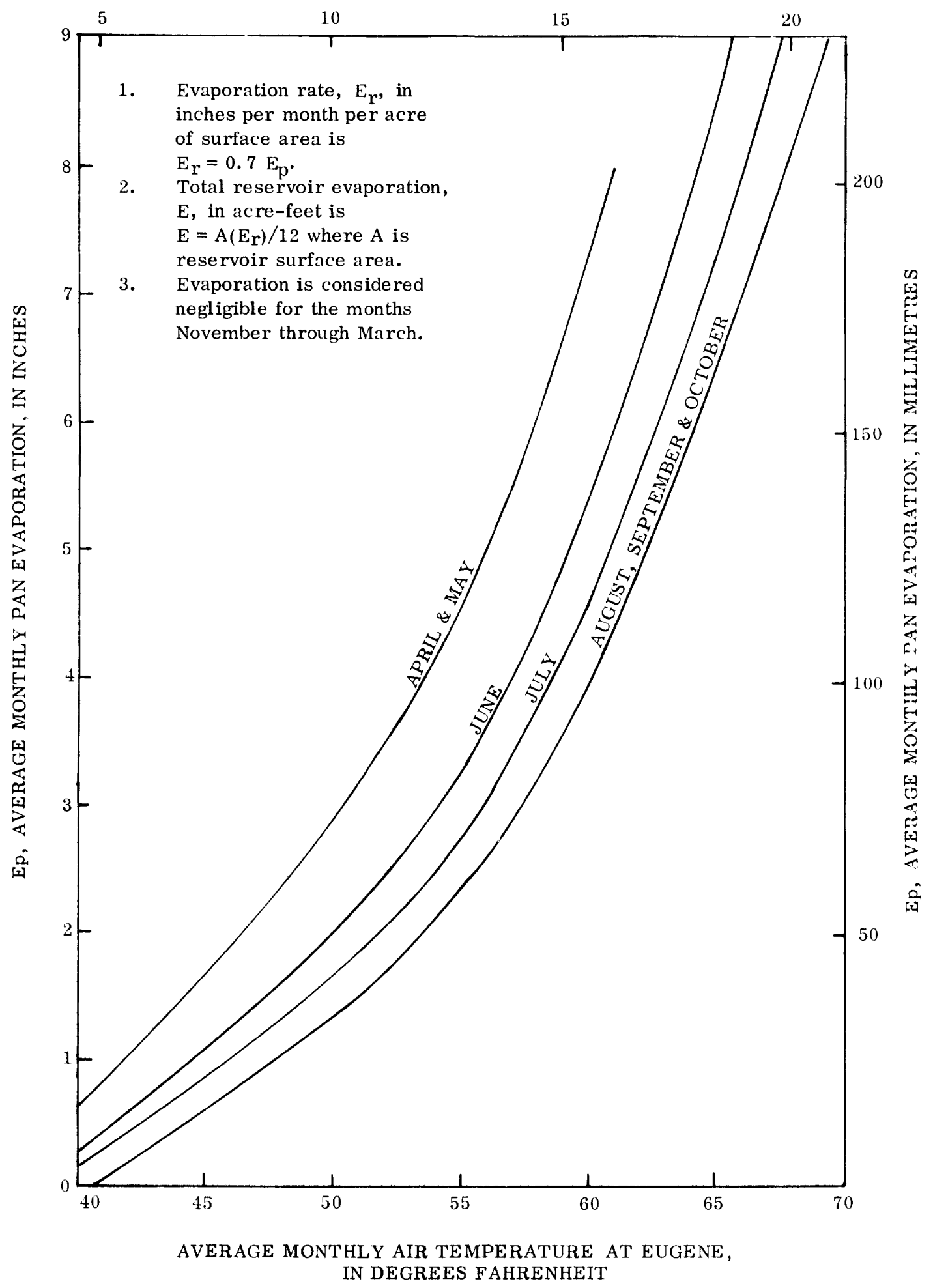

FiguRE 7.-Evaporation relations for the Willamette River basin. 
TABLE 6.-Summary of model verification results

\begin{tabular}{|c|c|c|c|c|c|c|c|c|c|c|c|c|c|c|c|}
\hline Year & Line & Type of data & Jan & Feb. & Mar. & Apr. & May & June & July & Aug. & Sept. & Oct. & Nov. & Dec. & $\begin{array}{c}\text { Average } \\
\text { annual }\end{array}$ \\
\hline 1970 & $\begin{array}{r}1 \\
2 \\
3 \\
4 \\
5 \\
6 \\
7 \\
8 \\
9 \\
10\end{array}$ & 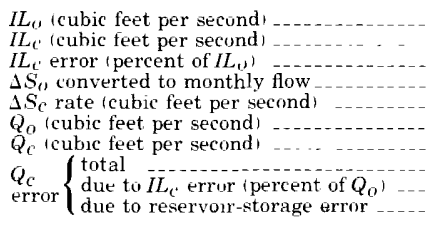 & $\begin{array}{r}91,190 \\
81,570 \\
-10.6 \\
18,770 \\
11,720 \\
72,420 \\
69,850 \\
-3.5 \\
-13.3 \\
9.7\end{array}$ & $\begin{array}{r}39.560 \\
38.210 \\
-3.4 \\
-17.490 \\
-1.355 \\
57.050 \\
39.560 \\
-307 \\
-2.4 \\
-28.3\end{array}$ & $\begin{array}{r}25,830 \\
27.860 \\
7.9 \\
7.419 \\
6,304 \\
18.410 \\
21.560 \\
17.1 \\
11.1 \\
6.1\end{array}$ & $\begin{array}{r}18,740 \\
21.540 \\
15.0 \\
5,025 \\
4,872 \\
13,710 \\
16,670 \\
21.6 \\
20.5 \\
1.1\end{array}$ & $\begin{array}{r}21,900 \\
24,440 \\
11.6 \\
2,771 \\
3,245 \\
19,130 \\
21,200 \\
10.8 \\
13.3 \\
-2.5\end{array}$ & $\begin{array}{r}8,251 \\
8.676 \\
5.1 \\
-564 \\
-451 \\
8, .15 \\
9,127 \\
3.5 \\
4.8 \\
-1.3\end{array}$ & $\begin{array}{r}3.719 \\
3.542 \\
-3.4 \\
-3.350 \\
-3.412 \\
7.069 \\
7.004 \\
-.9 \\
-1.8 \\
9\end{array}$ & $\begin{array}{r}2,505 \\
2.124 \\
-15.2 \\
-5.025 \\
-4,856 \\
7,530 \\
6.834 \\
-9.2 \\
-5.1 \\
-42\end{array}$ & $\begin{array}{r}3.744 \\
3.601 \\
-3.8 \\
-5,295 \\
-3.356 \\
9,039 \\
6.957 \\
-23.0 \\
-1.6 \\
-215\end{array}$ & $\begin{array}{r}6,524 \\
7,1 \times 6 \\
10.2 \\
-6.206 \\
-5,274 \\
12,730 \\
12,460 \\
-2.1 \\
5.2 \\
-7.3\end{array}$ & $\begin{array}{r}29,460 \\
31,260 \\
6.1 \\
-1,208 \\
-8,882 \\
30,710 \\
40,140 \\
30.7 \\
5.8 \\
24.9\end{array}$ & $\begin{array}{r}43,010 \\
38,440 \\
-10.6 \\
-3.599 \\
0 \\
46,610 \\
38.440 \\
-17.5 \\
-9.8 \\
-7.7\end{array}$ & $\begin{array}{r}24,520 \\
24,010 \\
-2.1 \\
-594 \\
-75 \\
25,110 \\
24,090 \\
-4.1 \\
-2.0 \\
-2.1\end{array}$ \\
\hline 1971 & $\begin{array}{r}1 \\
2 \\
3 \\
4 \\
5 \\
6 \\
7 \\
8 \\
9 \\
10\end{array}$ & 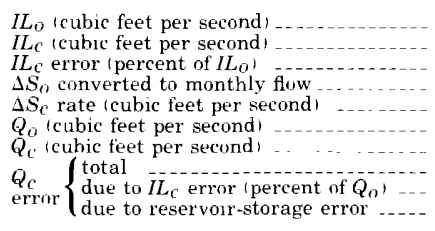 & $\begin{array}{r}86,830 \\
79.720 \\
-8.2 \\
9.735 \\
9,043 \\
77,100 \\
70,680 \\
-8.3 \\
-9.2 \\
9\end{array}$ & $\begin{array}{r}39.800 \\
36.770 \\
-7.6 \\
263 \\
2.622 \\
39,540 \\
34,150 \\
-136 \\
-7.7 \\
-6.0\end{array}$ & $\begin{array}{r}51,800 \\
51,830 \\
11 \\
6,145 \\
6,428 \\
45,650 \\
45,400 \\
-.5 \\
.1 \\
-.6\end{array}$ & $\begin{array}{r}38.140 \\
40,010 \\
4.9 \\
4.822 \\
6.289 \\
33.320 \\
33.720 \\
1.2 \\
56 \\
-4.4\end{array}$ & $\begin{array}{r}28,610 \\
28,850 \\
8 \\
4,545 \\
1,912 \\
24,070 \\
26,940 \\
11.9 \\
1.0 \\
10.9\end{array}$ & $\begin{array}{r}19.430 \\
19,170 \\
-1.3 \\
-21 \\
43 \\
19.450 \\
19.130 \\
-1.6 \\
-1.3 \\
-.3\end{array}$ & $\begin{array}{r}8.831 \\
8.170 \\
-7.5 \\
-612 \\
-1.410 \\
9,443 \\
9.580 \\
1.5 \\
-7.0 \\
8.4\end{array}$ & $\begin{array}{r}4.126 \\
3.909 \\
-5.2 \\
-5.595 \\
-3.552 \\
9.540 \\
7.461 \\
-21.8 \\
-2.3 \\
-19.5\end{array}$ & $\begin{array}{r}6.768 \\
6,705 \\
-.9 \\
-5,922 \\
-3,267 \\
12,690 \\
9,972 \\
-21.4 \\
-209\end{array}$ & $\begin{array}{r}7,757 \\
8.580 \\
10.6 \\
-8.453 \\
-9,160 \\
16.210 \\
17,740 \\
9.4 \\
5.1 \\
4.4\end{array}$ & $\begin{array}{r}35,500 \\
39,900 \\
12.4 \\
1,815 \\
-8.882 \\
33,690 \\
48.780 \\
44.8 \\
13.1 \\
31.8\end{array}$ & $\begin{array}{r}63.830 \\
56,340 \\
-11.7 \\
-8.296 \\
0 \\
72,130 \\
56,340 \\
-21.9 \\
-10.4 \\
-11.5\end{array}$ & $\begin{array}{r}32,640 \\
31,680 \\
-2.9 \\
-138 \\
0 \\
32,770 \\
31,680 \\
-3.3 \\
-29 \\
-.4\end{array}$ \\
\hline 1972 & $\begin{array}{r}1 \\
2 \\
3 \\
4 \\
5 \\
6 \\
7 \\
8 \\
9 \\
10 \\
\end{array}$ & 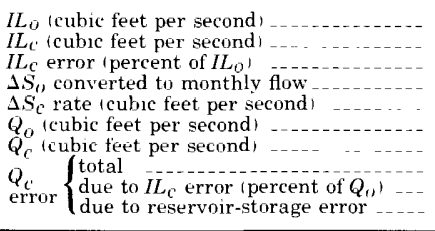 & $\begin{array}{r}78,040 \\
73,750 \\
-5.5 \\
8.911 \\
405 \\
69,130 \\
73,340 \\
6.1 \\
-6.2 \\
12.3\end{array}$ & $\begin{array}{r}56,320 \\
56,610 \\
5 \\
5.348 \\
1 ., 180 \\
50.970 \\
44.430 \\
-12.8 \\
.6 \\
-13.4\end{array}$ & $\begin{array}{r}79,060 \\
76,700 \\
-30 \\
5,393 \\
6.428 \\
73,670 \\
70.270 \\
-4.6 \\
-3.2 \\
-1.4\end{array}$ & $\begin{array}{r}37.100 \\
39.150 \\
55 \\
4.107 \\
6.289 \\
32.990 \\
32.860 \\
-.4 \\
6.2 \\
-6.6\end{array}$ & $\begin{array}{r}29.160 \\
28,840 \\
-1.1 \\
3,944 \\
1,920 \\
25,220 \\
26.920 \\
6.7 \\
-1.3 \\
8.0\end{array}$ & $\begin{array}{r}15,760 \\
14,480 \\
-8.1 \\
5 \\
-1.8 \\
15,760 \\
14,500 \\
-80 \\
-8.1 \\
.1\end{array}$ & $\begin{array}{r}6,469 \\
5,285 \\
-18.3 \\
-980 \\
-2,206 \\
7,449 \\
7.491 \\
6 \\
-15.9 \\
16.5\end{array}$ & $\begin{array}{r}4,052 \\
3.492 \\
-13.8 \\
-4.527 \\
-3.796 \\
8.579 \\
7.288 \\
-150 \\
-6.5 \\
-8.5\end{array}$ & $\begin{array}{r}4.374 \\
4.164 \\
-4.8 \\
-7.996 \\
-3,388 \\
12,370 \\
7.552 \\
-389 \\
-1.7 \\
-37.3\end{array}$ & $\begin{array}{r}4.864 \\
5,119 \\
5.2 \\
-6.086 \\
-7,951 \\
10.950 \\
13,060 \\
193 \\
2.3 \\
17.0\end{array}$ & $\begin{array}{r}10,070 \\
10,590 \\
5.2 \\
-6,030 \\
-8.882 \\
16.100 \\
19.470 \\
209 \\
3.2 \\
17.7\end{array}$ & $\begin{array}{r}38.420 \\
35,220 \\
-8.3 \\
68.5 \\
0 \\
37.740 \\
35.220 \\
-67 \\
-8.5 \\
1.8\end{array}$ & $\begin{array}{r}30,240 \\
29,360 \\
-2.9 \\
219 \\
0 \\
130,020 \\
29,360 \\
-22 \\
-2.9 \\
.7\end{array}$ \\
\hline 1973 & $\begin{array}{rr}1 & 1 \\
2 & 1 \\
3 & 1 \\
4 & \\
5 & \\
6 & \\
7 & \\
8 & \\
9 & \\
10 & \end{array}$ & 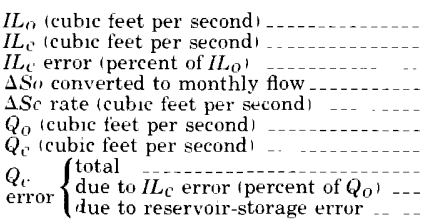 & $\begin{array}{r}37,950 \\
34,420 \\
-9.3 \\
296 \\
0 \\
37.650 \\
34,420 \\
-8.6 \\
-94 \\
.8\end{array}$ & $\begin{array}{r}16.420 \\
18,300 \\
11.4 \\
3,572 \\
3,282 \\
12,850 \\
15.020 \\
16.9 \\
146 \\
2.3\end{array}$ & $\begin{array}{r}22,870 \\
24,660 \\
7.8 \\
6,658 \\
5,489 \\
16.210 \\
19,170 \\
18.3 \\
110 \\
7.2\end{array}$ & $\begin{array}{r}20,190 \\
24,540 \\
21.5 \\
7,109 \\
6,003 \\
13,080 \\
18,540 \\
41.7 \\
33.3 \\
8.5\end{array}$ & $\begin{array}{r}11,500 \\
13,160 \\
14.4 \\
3.797 \\
2.725 \\
7.701 \\
10.440 \\
35.6 \\
216 \\
13.9\end{array}$ & $\begin{array}{r}6,875 \\
6,767 \\
-1.6 \\
336 \\
-188 \\
6.539 \\
6,955 \\
6.4 \\
-1.7 \\
8,0\end{array}$ & $\begin{array}{r}3,522 \\
3,111 \\
-11.7 \\
-2,536 \\
-2,889 \\
6.058 \\
6,000 \\
1.0 \\
-6.8 \\
5.8\end{array}$ & $\begin{array}{r}2.489 \\
2.093 \\
-15.9 \\
-4,091 \\
-3.907 \\
6,580 \\
6.000 \\
-8.8 \\
-6.0 \\
-2.8\end{array}$ & $\begin{array}{r}4,966 \\
4,722 \\
-4.9 \\
-3,081 \\
-1,278 \\
8.047 \\
6,000 \\
-25.4 \\
-3.0 \\
-22.4\end{array}$ & $\begin{array}{r}6,653 \\
--- \\
-1.571 \\
13,970 \\
8.224 \\
-41.1 \\
-.- \\
--.\end{array}$ & $\begin{array}{r}63,080 \\
-7 . \\
-7,441 \\
70,440 \\
70,520 \\
.1 \\
-. \\
-.-\end{array}$ & $\begin{array}{r}74,960 \\
-\ldots \\
2,157 \\
85,930 \\
72,800 \\
-15.3 \\
- \\
-\end{array}$ & $\begin{array}{r}\left.1^{2}\right) \\
23,060 \\
1^{2} \\
\left.1^{2}\right) \\
183 \\
323,600 \\
+22,880 \\
-3 . \\
1^{2} \\
(2)\end{array}$ \\
\hline
\end{tabular}

1Adjusted to a 28-day February since HEC-3 1gnores leap year.

${ }^{3}$ Final reservoir-storage data unavailable at time of analysis.

${ }^{4}$ October through December results are based on preliminary observed streamflows at all gaging stations. 
sults, are within \pm 15 percent of the $I L_{o}$ values which are based on observed data (table 7 and fig. 8). This is especially gratifying considering the vast opportunity for discrepancies in the (1) correlations for natural inflows, (2) diversion data, and (3) evaporation data. The errors in the annual average flow for 1970-73 are all less than 3 percent.

Additional insight to the modeling error can be gained by subtracting equation $2 \mathrm{a}$ from $2 \mathrm{~b}$ and rearranging to obtain

$$
Q_{c}-Q_{o}=\left(I L_{c}-I L_{o}\right)+\left(\Delta S_{o}-\Delta S_{c}\right) .
$$

Furthermore, multiplying through by $100 / Q_{o}$ results in

$$
\begin{aligned}
\left(\frac{Q_{c}-Q_{o}}{Q_{o}} \times 100\right)= & \left(\frac{I L_{c}-I L_{o}}{Q_{o}} \times 100\right)+ \\
& \left(\frac{\Delta S_{o}-\Delta S_{c}}{Q_{o}} \times 100\right) .
\end{aligned}
$$

The three bracketed terms in equation 5 , from left to right, represent (fig. 8) (1) total $Q_{c}$ error, (2) $Q_{c}$ error due to $I L_{c}$ error, and (3) $Q_{c}$ error due to reservoir-storage error. Table 6 (lines 8-10) summarizes these errors (with some roundoff error). Generally, errors due to reservoir-storage error are more significant than those due to $I L_{c}$ error (tables 7 and 8 and fig. 8), especially when the total $Q_{c}$ error is large.

Most of the error related to reservoir storage is due to differences in actual reservoir operation as compared to the reservoir operatior in the reservoir-system model. The summation of both the storage changes and the total storage for 11 reservoirs in the Willamette River basin reservoir system (Big Cliff and Dexter are omitted) for the rule curves defined for the model are tabulated in table 9 . Figure 9 illustrates the operation differences between the model and the actual reservoir system.

Operational differences are a commor problem in reservoir-release modeling. Rule curves are formulated during the reservoir's design phase in such a way that benefits from the reservoir will be maximized over a long period. Essentially, they reflect the operation of the reservoir for "average" hydrologic conditions. Departures of the hydrologic conditions from "average" frequently necessitate deviations from the design rule curve. A good example of such a case is the limited snowfall in the winter of 1972-73. Even by holding spring flows relatively low, it was only possible to fill the reservoir system to about 92 percent of desired capacity. Therefore, to meet desired flow objectives in July through September, system storage was depleted to less than 85 percent of desired capacity in August. The HEC-3 model (in its present form) was not capable of such anticipation and only filled the system to about 76 percent and depleted it to less than 65 percent of desired capacity.

Design rule curves (or parts thereof) may also become outdated if new objectives are considered.

TABLE 7.-Model errors classified by absolute error limits

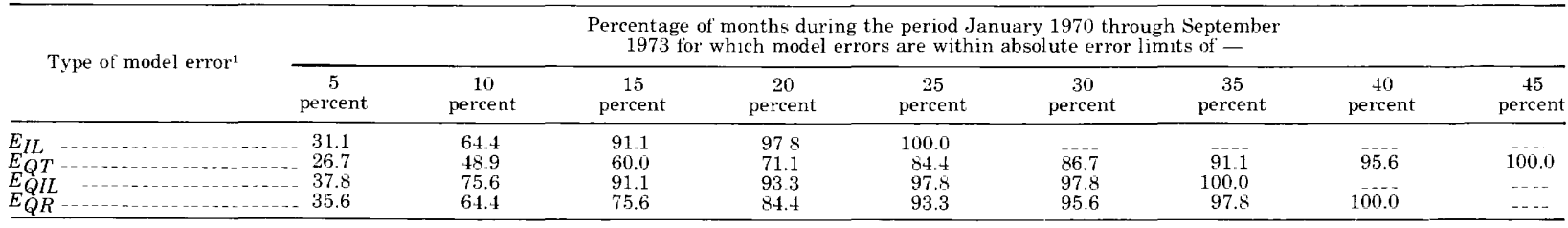

'These symbols are used in this table and in table 8 and figure 8 i to indicate absolute magnitude of the model errors as follows:

$E_{I L}-\mathrm{IL}_{\mathrm{c}}$ error lline 3 , table 6 ।

$E Q T$-total $Q_{c}$ error (line $\overline{8}$, table b)

$E_{Q I L}-Q_{c}$ error due to $I L_{c}$. error iline 9 , table 6

\begin{tabular}{|c|c|c|c|c|c|c|c|c|c|c|c|c|c|}
\hline & & \multicolumn{12}{|c|}{ Month } \\
\hline & & Jan. & Feb. & Mar & Apr. & May & June & July & Aug. & Sept. & Oct. & Nos. & Dec. \\
\hline $\begin{array}{c}\text { Number } \\
\text { of } \\
\text { observations }\end{array}$ & $\begin{array}{l}\text { Total } \\
E_{Q T}>15 \text { percent } \\
E_{Q I L}>E_{Q R} \\
E_{Q R}>E_{Q I L}\end{array}$ & $\begin{array}{c}4 \\
0 \\
---- \\
--- \\
\end{array}$ & $\begin{array}{l}4 \\
2 \\
1 \\
1\end{array}$ & $\begin{array}{c}4 \\
2 \\
2 \\
---\end{array}$ & $\begin{array}{c}4 \\
2 \\
2 \\
--- \\
\end{array}$ & $\begin{array}{r}4 \\
1 \\
1 \\
--- \\
\end{array}$ & $\begin{array}{c}4 \\
0 \\
--- \\
--- \\
\end{array}$ & $\begin{array}{c}4 \\
0 \\
---- \\
-\cdots\end{array}$ & $\begin{array}{c}4 \\
1 \\
-1\end{array}$ & $\begin{array}{c}4 \\
4 \\
-- \\
4\end{array}$ & $\begin{array}{c}3 \\
1 \\
-1\end{array}$ & $\begin{array}{c}3 \\
3 \\
- \\
-\end{array}$ & $\begin{array}{l}3 \\
2 \\
1 \\
1\end{array}$ \\
\hline $\begin{array}{l}\text { Average } \\
\text { absolute } \\
\text { error } \\
\text { (percent) }\end{array}$ & $\begin{array}{l}E_{Q T} \\
E_{Q I L} \\
E_{Q R}-1,\end{array}$ & $\begin{array}{l}---- \\
--- \\
---\end{array}$ & $\begin{array}{r}23.8 \\
8.5 \\
15.3\end{array}$ & $\begin{array}{r}17.7 \\
11.0 \\
6.7\end{array}$ & $\begin{array}{r}31.7 \\
26.9 \\
4.8\end{array}$ & $\begin{array}{l}35.6 \\
21.6 \\
13.9\end{array}$ & $\begin{array}{l}--- \\
--- \\
---\end{array}$ & $\begin{array}{l}--- \\
--- \\
---\end{array}$ & $\begin{array}{r}21.8 \\
2.3 \\
19.5\end{array}$ & $\begin{array}{r}27.2 \\
1.7 \\
25.5\end{array}$ & $\begin{array}{r}19.3 \\
2.3 \\
17.0\end{array}$ & $\begin{array}{r}32.1 \\
7.4 \\
24.8\end{array}$ & $\begin{array}{r}19.7 \\
10.1 \\
9.6\end{array}$ \\
\hline
\end{tabular}

$E_{Q R}-Q_{C}$ error due to reservoir-storage error lline 10 , table 6

TABLE 8.-Summary of modeling errors with absolute value exceeding 15 percent 

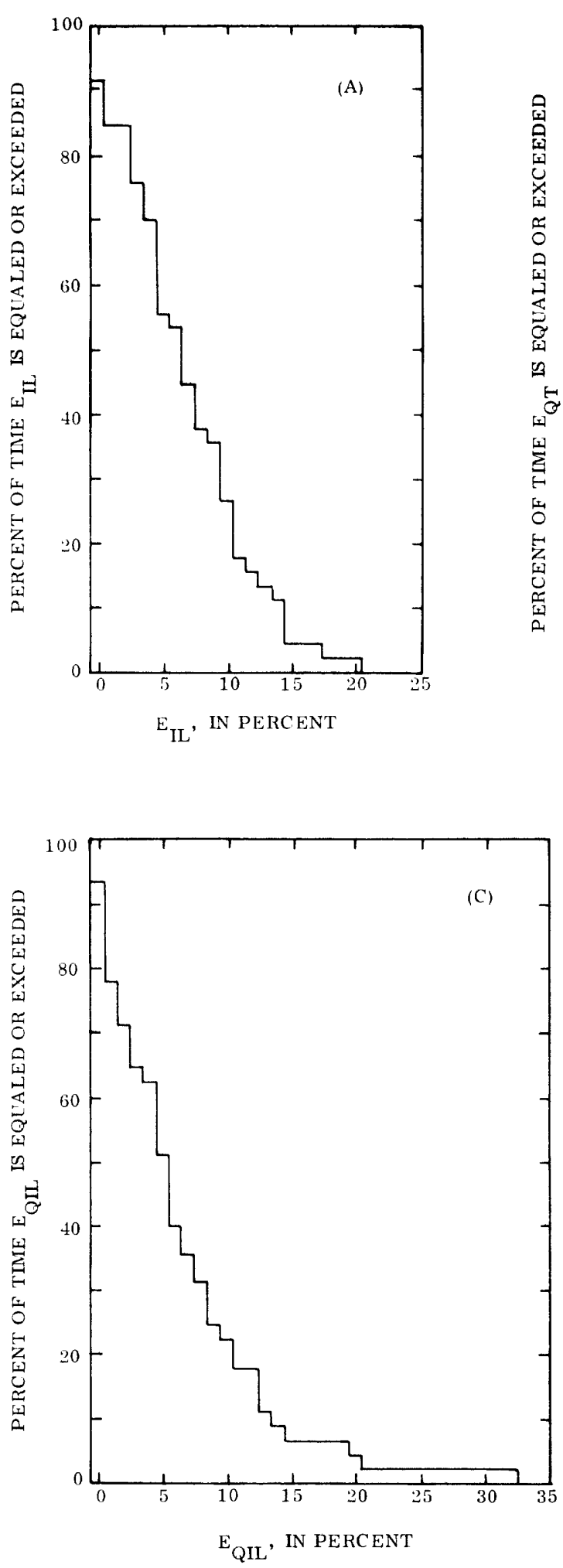
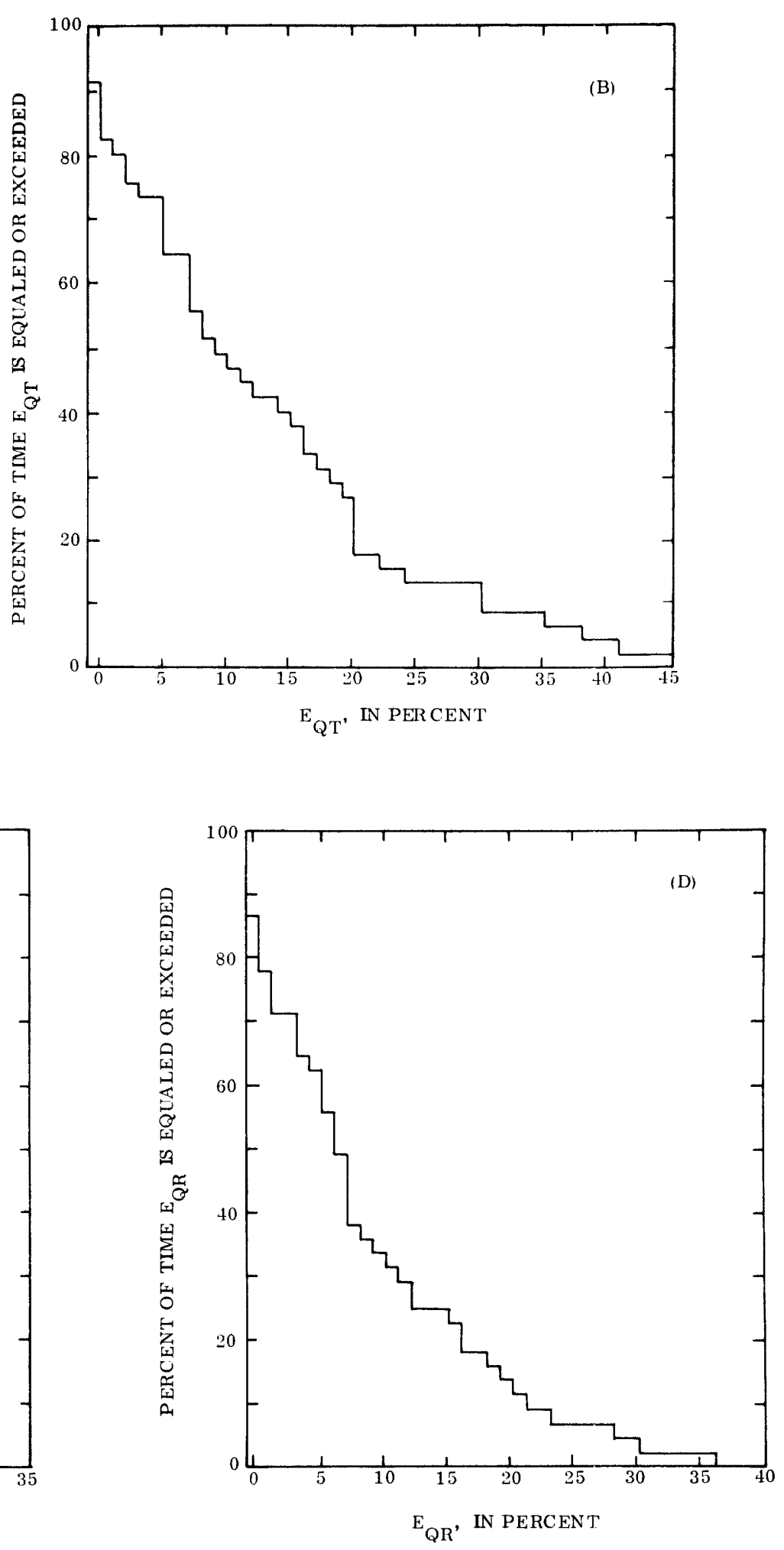

Figure 8.-Distribution of model errors, January 1970 through September 1973. A, $I L_{c}$ error. B, Total $Q_{c}$ error. C, $Q_{c}$ error due to $I L_{c}$ error. D, $Q_{c}$ error due to reservoir-storage error. 
TABLE 9.-Summation of total end-of-month storage and monthly storage changes specified by the design rule curces for 11 reservoirs in the Willamette River basin reservoir system

\begin{tabular}{|c|c|c|c|c|c|c|}
\hline $\begin{array}{c}\text { System } \\
\text { storage }^{l}\end{array}$ & January & February & March & April & May & June \\
\hline $\begin{array}{l}\text { End-of-month total } \\
\text { Change during month }\end{array}$ & $\begin{array}{r}715.74 \\
0\end{array}$ & $\begin{array}{r}1.417 .30 \\
701.56\end{array}$ & $\begin{array}{r}1,812.50 \\
395.20\end{array}$ & $\begin{array}{r}2,186.70 \\
374.20\end{array}$ & $\begin{array}{r}2,306.82 \\
120.12\end{array}$ & $\begin{array}{r}2,306.82 \\
0\end{array}$ \\
\hline $\begin{array}{l}\text { System } \\
\text { storage }^{1}\end{array}$ & July & August & September & October & November & December \\
\hline
\end{tabular}

1Storage quantities. shown in thousands of acre-feet, represent summation of individual design rule curves for the entire system, with the exception of Big Cliff and Dexter reregulation reservoirs.

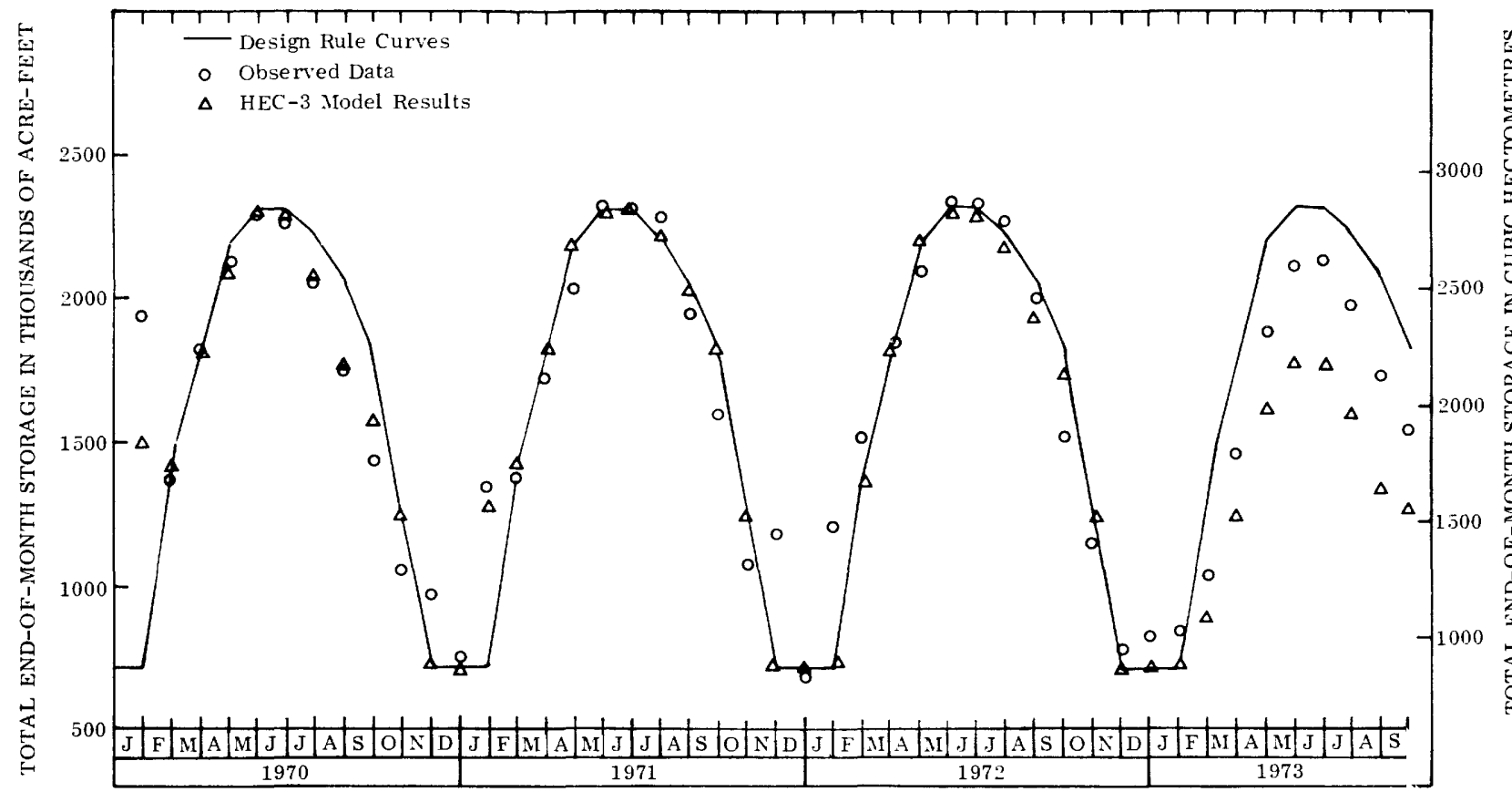

FIGURE 9.—Comparison of design, observed, and computed reservoir-system storage.

This has occurred in the Willamette River basin where increased flows in late August and in September are now used to stimulate fall fish runs. Table 6 readily reveals this effect with $Q_{o}$ consistently higher than $Q_{c}$ in August and September. Revision of the rule curve definitions in the model would have eliminated this particular bias, but detailed information was not available to make the revision for this study.

Other general possibilities for deviation from the design rule curve at individual reservoirs are (1) floods which require temporary use of the flood control pool, (2) special operational procedures to optimize short-term power production in the basin (especially if a portion of the total generation capacity is inoperable), and (3) ter porary storage depletion and (or) discontinuation of releases for maintenance reasons.

Another important factor to consider in the discussion of the HEC-3 model errors is the combination of temporary flood storage and the monthly time increment. Several instances can be found where the end-of-month deviatior above the rule curve (fig. 9) is due to a flood occurring late in the month. An examination of okserved daily data reveals that the system storage was depleted to the design rule curve shortly into the next month. Evacuation of the flood waters any 
sooner would have created unnecessary flooding below the reservoirs.

In summary, the verification results were considered acceptable. The HEC-3 model duplicated the actual system fairly well when considering that (1) some of the errors are due to the monthly time increment (which tend to balance out over two or more months) and (2) the rule curve defined in the model could be altered to more closely reflect current operating procedures. The $I L_{c}$ error analysis provided confidence in the input data used to define the natural streamflows, the diversions, and the evaporation for the system as a whole.

\section{APPLICATIONS OF THE MODEL}

The frequency-discharge relations shown in figure 10 can be used to estimate the low-flow characteristics required to satisfy the first two modeling objectives. The lower relation is based on the unregulated, monthly streamflow at Salem for 1926-73. These streamflow data (developed to satisfy part of the model input requirements) are an estimate of the natural flows that would have occurred at Salem had the reservoir system never been developed. Simulated monthly streamflows at Salem were used to determine the upper relation. These simulated streamflow data are the output from the model applied as described in the verification procedure except that unregulated streamflow data and evaporation data for 192673 were input to the model. Thus, these simulated flows represent the homogeneous, 48-year record of monthly streamflow that would have occurred at Salem had the existing (1973) reservoir system, subjected to present (1970) flow diversions, been in operation since 1926. Estimates of annual minimum low-flow rates based on these relations should be significantly more reliable than those based on available data (Hardison, 1969), assuming that model results are of acceptable accuracy.

A comparison of these relations provides an impressive picture of the increase in the annual monthly minimum low flows made possible by the reservoir system. These relations can also provide the critical low-flow data required for input to the DO model. Assume, for example, that minimum DO concentrations for the Willamette River at Salem occur during the annual minimum 7-day low-flow period. The relation shown in figure 5 can be used (as illustrated in a sub equent example) to estimate annual minimum 7 -day low flows from annual minimum monthly low flows. Such estimates of 7-day low-flow rates, for both regulated and unregulated conditions, can be input to the DO model to compute the anrual minimum DO concentration for the entire range of low-flow recurrence probabilities. The resultant frequency-DO concentration relations provide a means of assessing the total impact of the existing reservoir system on minimum DO concentrations at Salem relative to the minimum DO concentrations that would have occurred at Salem under natural conditions for the same 48-year period.

The third modeling objective wes to develop a model which could be used to estimate streamflows for various planning and manage-

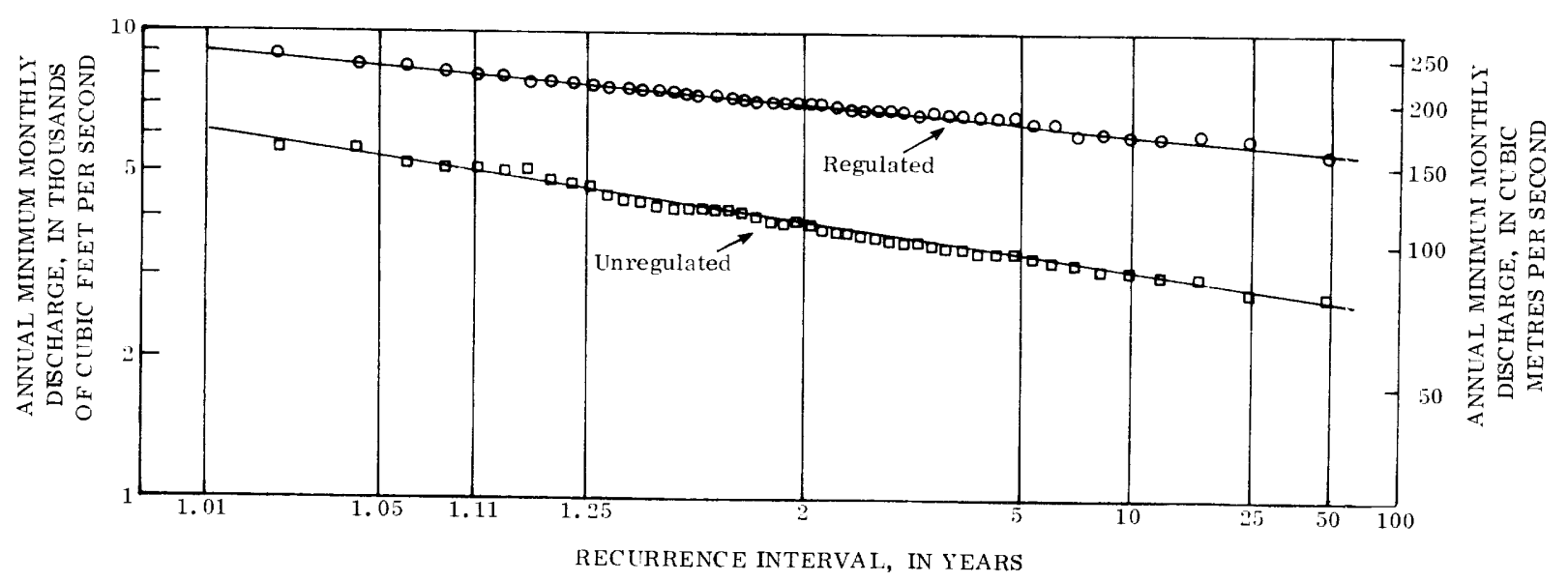

Figure 10.-Frequency-discharge relations at Salem, 1926-73, computed from a simulated streamflow for existing (regulated) conditions and from estimated streamflow for natural (unregulated) conditions. 
ment alternatives. Such alternatives or conditions might include (1) different demands on the system (such as 1980, 2000, or 2020 flow diversions), (2) different system-operation schemes (such as deemphasis and (or) placing more emphasis on one or more of the various authorized uses), (3) addition of reservoirs to the system, (4) the occurrence of more severe hydrologic conditions (such as more extreme droughts than have been experienced), and (5) combinations of the above, ad infinitum.

The scope of this report does not permit analysis of all reasonable alternatives. However, to illustrate this type of model application, three additional simulations were performed. Each of these three simulations were identical to the previous 48-year simulation, except that the flow diversions used were those estimated for the years 1980,2000 , and 2020. Thus, including the previous simulation, 1926-73 data sequences of monthly streamflows reflecting four levels of estimated flow diversions (table 4) are available for comparison. Frequency-discharge relations of annual minimum monthly flows for all four simulations are presented in figure 11 . These relations may be used to determine the annual minimum monthly low flow for any recurrence interval (hereafter denoted by ${ }_{t} Q_{m}$, where $t$ is the recurrence interval and $Q_{m}$ denotes average monthly flow rate).

Also, as mentioned above, estimates of annual minimum 7-day low flows for any recurrence interval ${ }_{t} Q_{7}$, where $t$ indicates recurrence interval and $Q_{7}$ denotes average 7-day flow rate) may be obtained using the ${ }_{t} Q_{m}$ data. The relation of annual minimum 7-day to annual minimum monthly low flows (fig. 5) may be expressed as

$$
\left.{ }_{t} Q_{7}=0.87{ }_{t} Q_{m}\right)
$$

Table 10 summarizes estimates of annual minimum monthly and annual minimum 7-day flows for the 1970 and 2020 levels of flow diversions. Also shown is the percent reduction in these flows resulting from the increased flow diversions projected for 2020 relative to the estimated flow diversions of 1970 . A DO model could be used to assess the impact that the increased flow diversions (reduced minimum flows) would have on DO concentrations.

Other low-flow periods may also be useful for assessing potential river-quality problems. For example, the temperature, sunlight, and flow conditions that combine for critical algal growth conditions may not coincide with the annual minimum 7-day or annual minimum monthly low-flow period. Frequency-discharge relation by calendar months might be more applicable. Figure 12 illustrates such relations for the individual months of July, August, and September based on the simulated streamflows reflecting the $1.970 \mathrm{di}-$ versions. Another potentially useful tool for river-quality assessment might be the annual minumum flow for multimonth periods. Figure 13 shows frequency-discharge relations for the annual minimum flow for consecutive 2- and 3month periods based on the simulated streamflows reflecting the 1970 diversions.

Only the Willamette River streamflow at Salem is utilized in the above examples. However, model results may be obtained at any control point (fig. 1). Therefore, similar evaluations could be made for the streamflow at several points for basinwide river-quality assessment.

\section{SUMMARY AND DISCUSSION}

A reservoir-system model provides a useful tool for improving an available streamflow data base which consists of streamflow data that have been observed during a period of changing conditions. Applicability of the U.S. Army Corps of Engineers' HEC-3 reservoir-system model to the Willamette River basin reservoir system is verified by comparing model results with olserved stream-flow at Salem for a 4-year period (197073. In general, modeling errors for this verification period are within reasonable limits. Predictive errors could possibly be reduced by (1) revising model input data to better define actual reservoir-system operation; (2) refining unregulated streamflow estimates by using waterbudget computations along with corralation analyses; and (3) using more refined evaporation estimates and including precipitation data in the analysis. This last source of possible error applies to the entire basin. The first two, however, could possibly be isolated to one or more segmonts of the basin by comparing model results with observed streamflow at other control points in the basin. Also, a longer verification period could add increased confidence in model applicabilit\%.

Despite the above limitations, the HEC-3 reservoir-system model is used for four simulations of monthly streamflow data to demonstrate 


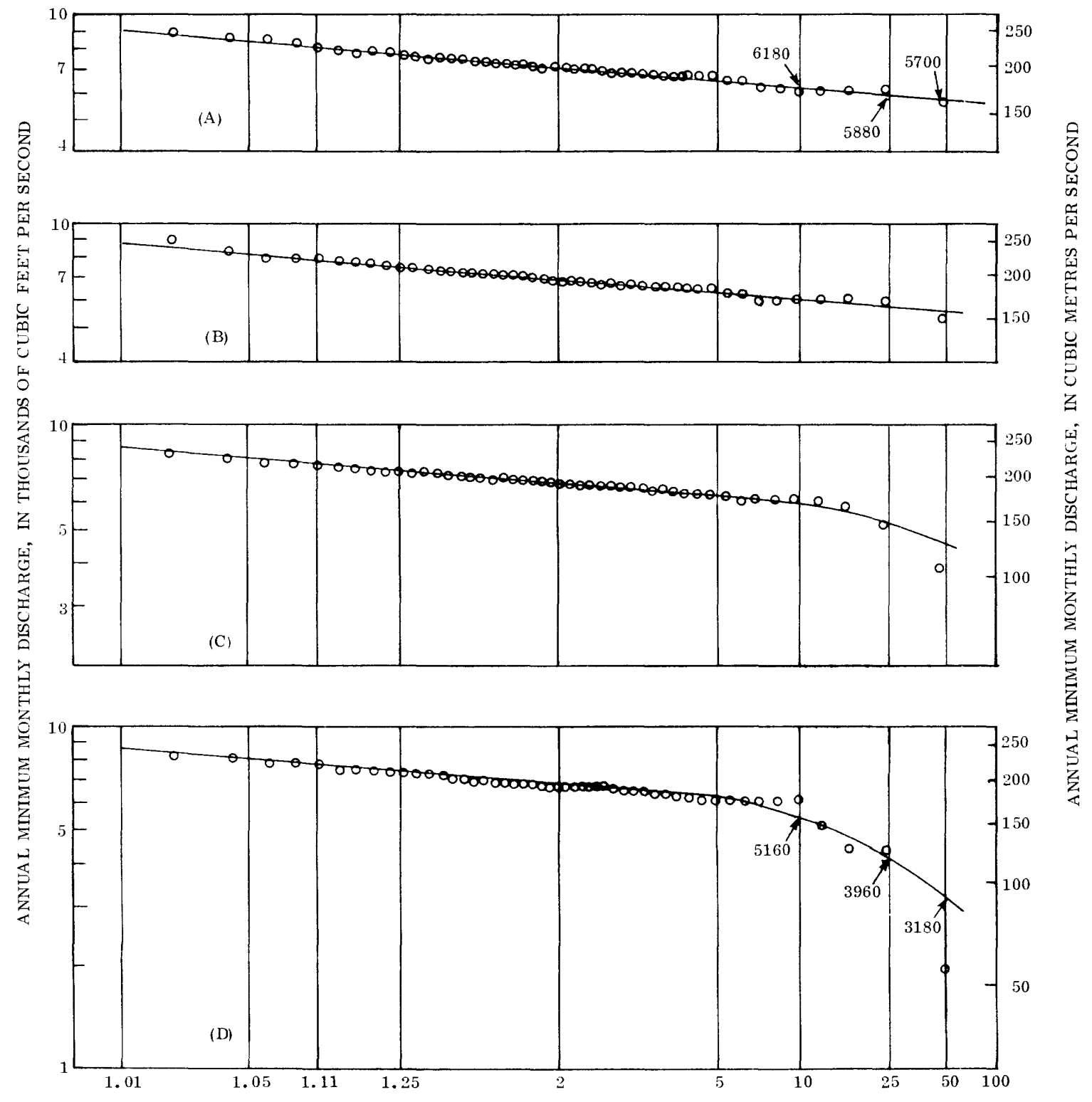

RECURRENCE INTERVAL, IN YEARS

Figure 11.-Frequency-discharge relations at Salem, 1926-73, computed from simulated streamflows reflecting the existing reservoir system subjected to different estimated flow diversions. A, 1970 flow diversions. B, 1980 flow diversions. C, 2000 flow diversions. D, 2020 flow diversions.

TABLE 10.-Determination of ${ }_{\mathrm{t}} \mathrm{Q}_{\mathrm{m}}$ and ${ }_{\mathrm{t}} \mathrm{Q}_{7}$ at Salem for the simulated streamflou's reflecting the 1970 and 2020 flou diversions

\begin{tabular}{|c|c|c|c|c|}
\hline $\begin{array}{l}\text { Simulation } \\
\text { using- }\end{array}$ & $\begin{array}{c}t \\
\text { (years) }\end{array}$ & $\begin{array}{l}t_{t} Q m^{1} \\
t^{1} \mathrm{ft}^{3 / \mathrm{s} 1}\end{array}$ & $\begin{array}{l}t^{Q} \mathrm{Q}^{2} \\
\left.\mid \mathrm{ft}^{3} / \mathrm{s}\right)\end{array}$ & $\begin{array}{l}\text { Reduction } \\
\text { in flow } \\
\text { ipercent }\end{array}$ \\
\hline $\begin{array}{c}1970 \\
\text { diversions }\end{array}$ & $\begin{array}{l}10 \\
25 \\
50\end{array}$ & $\begin{array}{l}6,180 \\
5,880 \\
5,700\end{array}$ & $\begin{array}{l}5,380 \\
5,120 \\
4,960\end{array}$ & $\ldots$ \\
\hline
\end{tabular}

${ }^{1}$ From figures 11 for 1970 and 2020 flow diversions.

${ }^{2}$ Computed by equation $6, t Q 7=0.87_{t} Q \mathrm{~m}$.
TABLE 10.-Determination of ${ }_{\mathrm{t}} \mathrm{Q}_{\mathrm{m}}$ and ${ }_{\mathrm{t}} \mathrm{Q}_{7}$ at Salem for the simulated streamflows reflecting the 1970 and 2020 flow diversions-Continued

\begin{tabular}{|c|c|c|c|c|}
\hline $\begin{array}{l}\text { Simulation } \\
\text { using- }\end{array}$ & $\begin{array}{c}t \\
\text { (years) }\end{array}$ & $\begin{array}{l}t \mathrm{Qm}^{1} \\
\left(\mathrm{tt}^{3 / \mathrm{s}}\right)\end{array}$ & $\begin{array}{l}t_{\mathrm{Q} 7^{2}} \\
\left(\mathrm{ft}^{3 / \mathrm{s}}\right)\end{array}$ & $\begin{array}{l}\text { Reduction } \\
\text { in flow } \\
\text { (percent })^{3}\end{array}$ \\
\hline $\begin{array}{c}2020 \\
\text { diversions }\end{array}$ & $\begin{array}{l}10 \\
25 \\
50\end{array}$ & $\begin{array}{l}5,160 \\
3,960 \\
3,180\end{array}$ & $\begin{array}{l}4,490 \\
3,450 \\
2,770\end{array}$ & $\begin{array}{l}17 \\
33 \\
44\end{array}$ \\
\hline
\end{tabular}

:Percent reduction of low flows at Salem reflecting 2020 diversions as compared to those reflecting 1970 diversions. 


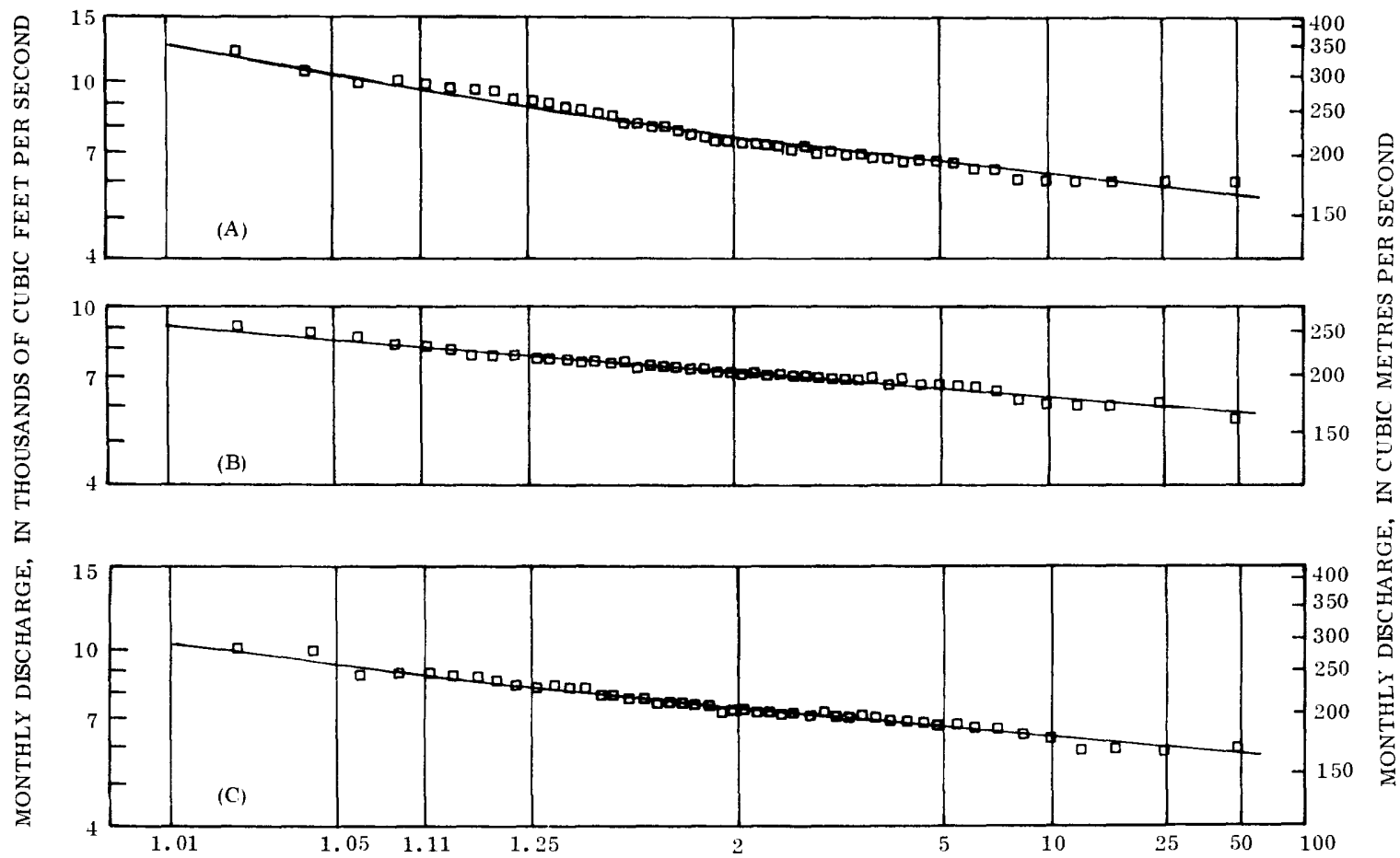

RECURRENCE INTERVAL, IN YEARS

Figure 12.-Frequency-discharge relations at Salem, 1926-73, computed from discharges for calendar months. A, July. B, August. C, September.

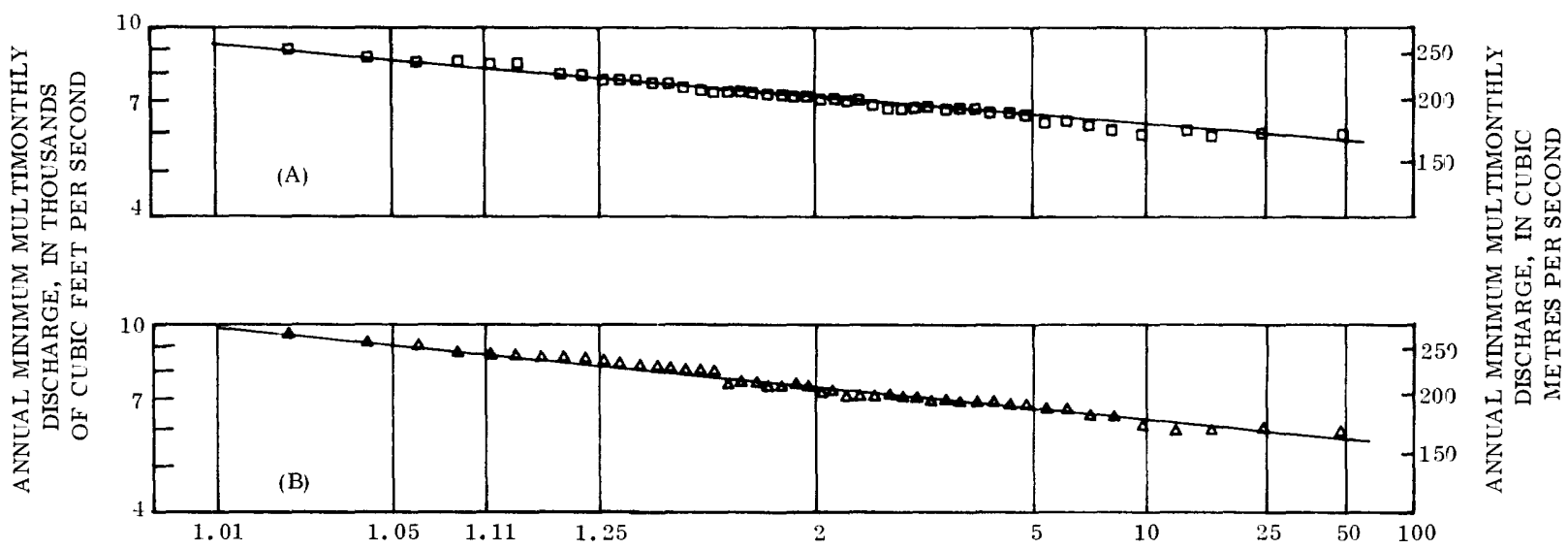

RECURRENCE INTERVAL, IN YEARS

FIgURE 13.-Frequency-discharge relations at Salem, 1926-73, computed from minimum multimonthly discharge. A, 2-month minimum discharge. $\mathrm{B}, 3$-month minimum discharge.

potential applications. Each simulation utilizes identical input data for (1) defining system inputs and losses with unregulated monthly streamflow and evaporation data for a 48-year period (192673 ) and (2) defining the operation and configura- tion of the existing reservoir system. Different diversion data, reflecting estimated flow diversions for the years 1970, 1980, 2000, and 2020, are used for each simulation.

Frequency-discharge relations of low flow at 
Salem based on these simulated streamflows for regulated conditions and on the estimated streamflow for natural conditions are used to demonstrate potential applications of simulated streamflow data. Detailed examples illustrate (1) use of low-flow characteristics reflecting existing conditions and those reflecting natural conditions as a basis for assessing the total impact that the existing reservoir system has had on DO concentrations at Salem and (2) use of low-flow characteristics reflecting existing conditions and those reflecting estimated 2020 flow diversions as a basis for assessing the impact that the higher flow diversions projected for the future will have on DO concentrations at Salem. Other potential applications of the reservoir-system model are briefly discussed.

Each reader, of course, is free to pass independent judgment as to the applicability of the simulated streamflow data. The author feels that the discharge-frequency relation based on the streamflow data simulated using estimated 1970 flow diversions (fig. 11A) is a more reliable estimate of long-term basin response to existing conditions that can be obtained by using the limited observed data that are applicable (fig. 3). Also, comparison of figures $11 \mathrm{~A}-\mathrm{D}$ provides a sound estimate as to the relative decrease in low flows as a result of increased future flow diversions.

Assuming that either (1) the model is adequate as described herein or (2) it can easily be altered to yield more acceptable results, the potential benefits of using it are obvious. It is hard to envi- sion any other tool that could provide such flexibility for analyzing planning or management alternatives in the Willamette River basin.

\section{REFERENGES CITED}

Draper, N. R., and Smith, H., 1966, Applied regression analysis: New York, John Wiley and Sons, Inc., 407 p.

Gleeson, G. W., 1972, The return of a river, the Willamette River, Oregon: Advisory Comm. Envirormental Sci. and Technology and Water Resources Inst., Oregon State Univ., Corvallis, $103 \mathrm{p}$.

Hardison, C. H., 1969, Accuracy of streamflov' characteristics, in Geological Survey research 1969: U.S. Geol. Survey Prof. Paper 650-D, p. D210-D214.

Hines, W. G., Rickert, D. A., McKenzie, S. W., and Bennett, J. P., 1975, Formulation and use of practical models for river-quality assessment: U.S. Geol. Survey Circ. 715-B, p. 13.

Jennings, M. E., Shearman, J. O., and Bauer, D. P., 1976, Selection of streamflow and reservoir-release models for river-quality assessment: U.S. Geol. Survey Circ. 715-E, $12 \mathrm{p}$.

Rickert, D. A., and Hines, W. G., 1975, A prastical framework for river-quality assessment: U.S. Geol. Survey Circ. 715-A, $17 \mathrm{p}$.

Texas Water Development Board, 1972, Economic optimization and simulation techniques for management of regional water resource systems, river kasin simulation model, SIMYLD-II program description: Texas Water Devel. Board, 106 p.

U.S. Army Corps of Engineers, 1968, HEC-3, reservoir systems analysis: Hydrol. Eng. Center Users Manual No. 23-53, 86 p.

U.S. Geological Survey, 1973, Water resources data for Oregon-part 1, surface water records: $409 \mathrm{p}$.

Willamette Basin Task Force, 1969, Appendix M, Willamette basin comprehensive study: Pacific Northwest River Basins Comm. Rept., p. II-1-II-34. 